\title{
Current Status and Future Strategies to Increase Secondary Metabolite Production from Cyanobacteria
}

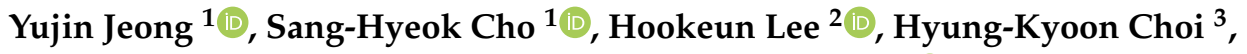 \\ Dong-Myung Kim ${ }^{4}$, Choul-Gyun Lee ${ }^{5}$, Suhyung Cho ${ }^{1, *(1)}$ and Byung-Kwan Cho ${ }^{1, *}$ \\ 1 Department of Biological Sciences and KAIST Institutes for the BioCentury, \\ Korea Advanced Institute of Science and Technology, Daejeon 34141, Korea; mist@kaist.ac.kr (Y.J.); \\ graysky@kaist.ac.kr (S.-H.C.) \\ 2 Institute of Pharmaceutical Research, College of Pharmacy, Gachon University, Incheon 21999, Korea; \\ hklee@gachon.ac.kr \\ 3 College of Pharmacy, Chung-Ang University, Seoul 06911, Korea; hykychoi@cau.ac.kr \\ 4 Department of Chemical Engineering and Applied Chemistry, Chungnam National University, \\ Daejeon 34134, Korea; dmkim@cnu.ac.kr \\ 5 Department of Biological Engineering, Inha University, Incheon 22212, Korea; leecg@inha.ac.kr \\ * Correspondence: shcho95@kaist.ac.kr (S.C.); bcho@kaist.ac.kr (B.-K.C.)
}

Received: 29 October 2020; Accepted: 23 November 2020; Published: 24 November 2020

\begin{abstract}
Cyanobacteria, given their ability to produce various secondary metabolites utilizing solar energy and carbon dioxide, are a potential platform for sustainable production of biochemicals. Until now, conventional metabolic engineering approaches have been applied to various cyanobacterial species for enhanced production of industrially valued compounds, including secondary metabolites and non-natural biochemicals. However, the shortage of understanding of cyanobacterial metabolic and regulatory networks for atmospheric carbon fixation to biochemical production and the lack of available engineering tools limit the potential of cyanobacteria for industrial applications. Recently, to overcome the limitations, synthetic biology tools and systems biology approaches such as genome-scale modeling based on diverse omics data have been applied to cyanobacteria. This review covers the synthetic and systems biology approaches for advanced metabolic engineering of cyanobacteria.
\end{abstract}

Keywords: cyanobacteria; photosynthesis; secondary metabolites; metabolic engineering; synthetic biology; systems biology; genome-scale model

\section{Introduction}

Cyanobacteria are oxygenic photosynthetic bacteria that can produce various secondary metabolites. Given the ability to utilize sunlight and atmospheric carbon dioxide $\left(\mathrm{CO}_{2}\right)$ as a part of the renewable photosynthetic process, cyanobacteria are considered sustainable bioproduction hosts [1]. A number of secondary metabolites naturally synthesized by cyanobacteria, such as carotenoids, phycocyanins, and squalene, are used in the pharmaceutical, cosmetic, and healthcare industries [2-4]. In addition, owing to their rapid growth and increased scope for engineering, multiple efforts have been made to utilize cyanobacteria as production hosts for valuable biochemicals by introducing heterologous pathways $[5,6]$.

While continuous development has been reported in metabolic engineering strategies for producing biochemicals in bacterial hosts, the synthetic biology approach accelerated the development by providing diverse genetic parts and engineering tools. For other model platforms such as Escherichia coli, there is an abundant catalog of genetic parts including synthetic promoters and ribosome binding sites (RBSs), which have been successfully introduced to improve gene expression in heterologous 
pathways [7]. However, owing to the lack of genetic parts for pathway engineering in cyanobacteria, application of metabolic engineering tools is limited [8]. Thus, development of various tools for pathway engineering and subsequent engineering strategies are required for industrial-scale production of target compounds in cyanobacteria.

With the recent progress in systems biology, genome-wide information of diverse layers such as the genome, transcriptome, translatome, proteome, metabolome, and interactome are being constantly accumulated [9]. Massive amounts of data formed the basis for establishment and development of an in silico genome-scale model (GEM) [10]. It is expected that the application of system-level approaches with the integration of omics data and GEM would address the existing limitations of cyanobacterial engineering. The current review not only describes the value-added secondary metabolites produced by cyanobacteria and current metabolic engineering approaches for their production but also introduces the synthetic and systems biology approach for further development.

\section{Secondary Metabolite Production by Cyanobacteria}

Bacteria produce two kinds of metabolites: primary metabolites essential for survival and secondary metabolites required for auxiliary purposes, such as stress responses, defense mechanisms, metal carrying, and signaling [11]. Secondary metabolites include terpenes, alkaloids, polyketides (PKs), non-ribosomal peptides (NRPs), and ribosomally synthesized and post-translationally modified peptides (RiPPs), which are produced via biosynthetic gene clusters (BGCs). BGCs are clusters of genes positioned in approximate proximity to each other for the production and processing of a compound. Cyanobacteria, being rich in BGCs, are capable of producing diverse secondary metabolites for various purposes, including toxins for defenses or protectants for relieving photodamage and oxidative stress (Table 1).

Table 1. Bioactive secondary metabolites produced in cyanobacteria.

\begin{tabular}{|c|c|c|c|c|}
\hline Class & Metabolite & Bioactivity & Producing Species & Ref. \\
\hline Terpene & Phycocyanin & $\begin{array}{c}\text { Antioxidant, } \\
\text { anti-inflammatory, } \\
\text { neuroprotective, } \\
\text { hepatoprotective }\end{array}$ & All cyanobacteria & [12-16] \\
\hline Terpene & Carotenoids & Antioxidant, sunscreen & All cyanobacteria & {$[17,18]$} \\
\hline Terpene & Squalene & Antioxidant & Phormidium & [19] \\
\hline Alkaloid & Saxitoxin & Neurotoxin & $\begin{array}{c}\text { Anabaena, Aphanizomenon, } \\
\text { Cylindrospermopsis, Lyngbya, } \\
\text { Planktothrix, }\end{array}$ & [20-22] \\
\hline Indole & Nostodione & Antifungal & Nostoc & [23] \\
\hline Indole alkaloid & Scytonemin & $\begin{array}{l}\text { Anti-inflammatory, } \\
\text { sunscreen }\end{array}$ & Scytonema, Nostoc & [24-27] \\
\hline Indole alkaloid & Hapalindole & $\begin{array}{c}\text { Antibacterial, } \\
\text { anti-tuberculosis, anticancer }\end{array}$ & Hapalosiphon & {$[28,29]$} \\
\hline $\begin{array}{l}\text { Alkaloid/Polyketide } \\
\text { synthase (PKS) }\end{array}$ & Anatoxin-a & $\begin{array}{c}\text { Neurotoxin, } \\
\text { anti-inflammatory }\end{array}$ & $\begin{array}{c}\text { Anabaena, Aphanizomenon, } \\
\text { Cylindrospermum, Oscillatoria, } \\
\text { Planktothrix }\end{array}$ & {$[30,31]$} \\
\hline Alkaloid/PKS & Aplysiatoxin & Cytotoxin, antiviral & Moorea & {$[32,33]$} \\
\hline $\begin{array}{l}\text { Alkaloid/Non-ribosomal } \\
\text { peptide synthetase (NRPS) }\end{array}$ & Lyngbyatoxin & Cytotoxin, dermatotoxin & Moorea & [34] \\
\hline Alkaloid/PKS-NRPS & Cylindrospermopsin & Cytotoxin & $\begin{array}{c}\text { Aphanizomenon, Cylindrospermopsis, } \\
\text { Oscillatoria, Raphidiopsis }\end{array}$ & [35-37] \\
\hline PKS & Fischerellin & $\begin{array}{l}\text { Antifungal, antialgal, } \\
\text { anti-cyanobacterial }\end{array}$ & Fischerella & [38] \\
\hline NRPS & $\beta$-N-methylamino-L-alanine & Neurotoxin & Anabaena, Nostoc & [39] \\
\hline NRPS & Cyanopeptolin & Protease inhibitor & Planktothrix, Microcystis & {$[40,41]$} \\
\hline PKS-NRPS & Microcystin & Hepatotoxin & $\begin{array}{c}\text { Microcystis, Nostoc, Planktothrix, } \\
\text { Anabaena }\end{array}$ & {$[40,42-45]$} \\
\hline PKS-NRPS & Nodularin & Hepatotoxin & Nodularia & [46] \\
\hline PKS-NRPS & Apratoxin & Anticancer & Lyngbya & [47] \\
\hline PKS-NRPS & Aeruginoside & Protease inhibitor & Planktothrix & {$[48]$} \\
\hline PKS-NRPS & Aeruginosin & Protease inhibitor & Microcystis, Planktothrix & {$[40,49]$} \\
\hline PKS-NRPS & Cryptophycins & Cytotoxin & Nostoc & {$[50]$} \\
\hline PKS-NRPS & Nostophycins & Cytotoxin & Nostoc & [51] \\
\hline PKS-NRPS & Curacins & Cytotoxin & Moorea & [52] \\
\hline PKS-NRPS & Hectochlorin & Cytotoxin & Moorea & [53] \\
\hline PKS-NRPS & Jamaicamides & Neurotoxin & Moorea & [54] \\
\hline
\end{tabular}


Table 1. Cont.

\begin{tabular}{|c|c|c|c|c|}
\hline Class & Metabolite & Bioactivity & Producing Species & Ref. \\
\hline PKS-NRPS & Dolastatin & $\begin{array}{l}\text { Cytotoxin, anticancer, } \\
\text { antiprotozoal }\end{array}$ & Moorea, Lyngbya, Symploca & {$[55,56]$} \\
\hline Lipopeptide & Antillatoxin & Neurotoxin & Moorea & [57] \\
\hline Lipopeptide & Carmabin & $\begin{array}{l}\text { Antimalarial, anticancer, } \\
\text { antiproliferative }\end{array}$ & Moorea & {$[58,59]$} \\
\hline Lipopeptide & Lyngbyabellin & Cytotoxin, antifungal & Moorea, Lyngbya & {$[60,61]$} \\
\hline Lipopeptide & Kalkitoxin & Neurotoxin & Moorea & [57] \\
\hline $\begin{array}{l}\text { Ribosomally synthesized } \\
\text { and post-translationally } \\
\text { modified peptide (RiPP) }\end{array}$ & Patellamide & Moderate cytotoxicity & Prochloron & [62] \\
\hline RiPP & Microviridin & Protease inhibitor & Microcystis, Planktothrix & {$[63,64]$} \\
\hline RiPP & Shinorin & Sunscreen & Anabaena, Nostoc & [65] \\
\hline Fatty acid amide & Besarhanamide A & $\begin{array}{l}\text { Moderate toxicity to brine } \\
\text { shrimp }\end{array}$ & Moorea & [66] \\
\hline Fatty acid amide & Semiplenamide & Toxicity to brine shrimp & Lyngbya & [67] \\
\hline Lipopolysaccharide & Lipopolysaccharides & Endotoxin & All cyanobacteria & [68] \\
\hline Polysaccharide & Polysaccharide & $\begin{array}{l}\text { Antitumor, antiviral, } \\
\text { antibacterial, } \\
\text { anti-inflammatory, } \\
\text { immunostimulant }\end{array}$ & All cyanobacteria & [69-71] \\
\hline Nucleoside & Toyocamycin & Antifungal & Tolypothrix & [72] \\
\hline Nucleoside & Tubercidin & Antifungal & Tolypothrix & [73] \\
\hline
\end{tabular}

\subsection{Prediction of Biosynthetic Gene Clusters (BGCs) in Cyanobacterial Genomes}

To investigate the secondary metabolites produced by cyanobacteria, 196 complete genome sequences of cyanobacteria available at the National Center for Biotechnology Information (NCBI) genome portal were inspected for BGCs using antiSMASH [74]. Thirty-three different types of BGCs were identified. The 196 complete genome sequences of cyanobacteria used in the BGC search were arranged according to the phylogenetic tree. The heatmap representing the numbers of each type of BGC found in each cyanobacterium showed that the cyanobacteria from the same genera had similar classes and numbers of BGCs (Figure 1A). It was evident that a single genome contained several BGCs with multiple occurrences. In particular, there were cyanobacteria with large number of bacteriocin, terpene, and non-ribosomal peptide synthetase (NRPS) BGCs, which accounted for $74.4 \%$ of the total predicted BGCs $(n=2119)$. For example, it was predicted that the genome of Moorea producens PAL-8-15-08-1 carries 18 NRPS BGCs. The most widely distributed BGC was the terpene BGC, which was found in all cyanobacteria except for two species (Limnospira fusiformis SAG 85.79 and Nodularia spumigena UHCC 0039). Terpene is essential for photosynthetic organisms. Undetected terpene BGCs in the two species could have resulted from the deviations in the BGC search criteria of antiSMASH. The 33 BGCs were classified according to their structural and functional similarities to the following categories: terpene, indole, PK synthase (PKS)/NRPS (type 1, 2, 3 PKSs, NRPS, cyclodipeptide synthase-based tRNA-dependent peptide, resorcinol, and siderophore), RiPP (bacteriocin, lanthidin, linear azole-containing peptide, microviridin, lasso peptide, cyanobactin, thiopeptide, trifolitoxin, proteusin, and lanthipeptide), lipid/saccharide/nucleoside (heterocyst glycolipid synthase, ladderane, arylpolyene, aminoglycoside/aminocyclitol, oligosaccharide, and nucleoside), and others (phosphonate, phenazine, ectoine, $\beta$-lactone, and homoserine lactone).

\subsection{Terpenes}

Terpene is a family of compounds with varying structures that occupies a large proportion of the natural products [75]. Terpenes are mainly produced by plants or fungi, as well as the bacterial species via mevalonate (MVA) pathway or methylerythritol-phosphate (MEP) pathway using acetyl-CoA or glyceraldehyde 3-phosphate and pyruvate as substrates [76]. While MVA and MEP pathways are mutually exclusive in most organisms, cyanobacteria mainly utilize the MEP pathway, using substrates generated during photosynthesis. The MEP pathway produces isomeric 5-carbon compounds, isopentyl pyrophosphate (IPP), and dimethylallyl pyrophosphate (DMAPP), which are further condensed into geranyl pyrophosphate (GPP), the building block in terpene biosynthesis. From the GPP, terpenes of varying structures can be generated. Terpenes conduct various cellular processes necessary for survival, such as the ubiquinone in the electron transport chain associated with cellular respiration, 
chlorophyll, carotenoids, and plastoquinones in photosynthetic processes, and hopanoids in cell membrane biosynthesis and stability (Figure 1B) [77]. In particular, photosynthetic cyanobacteria contain a wide variety of carotenoids. Most of the genome-sequenced cyanobacteria have $\beta$-carotene BGC. Production of other carotenoids, such as zeaxanthin and nostoxanthin are dependent on the presence of carotenogenesis pathway connected to $\beta$-carotene $[3,78]$. The terpene compounds, including the carotenoids obtained from cyanobacteria are of industrial value owing to their various applications. For example, $\beta$-carotene, astaxanthin, and canthaxanthin are used as color additives or animal feeds. Phycocyanin exhibits anti-oxidant, anti-inflammatory, neuroprotective, and hepatoprotective effects [2,13,79].

A

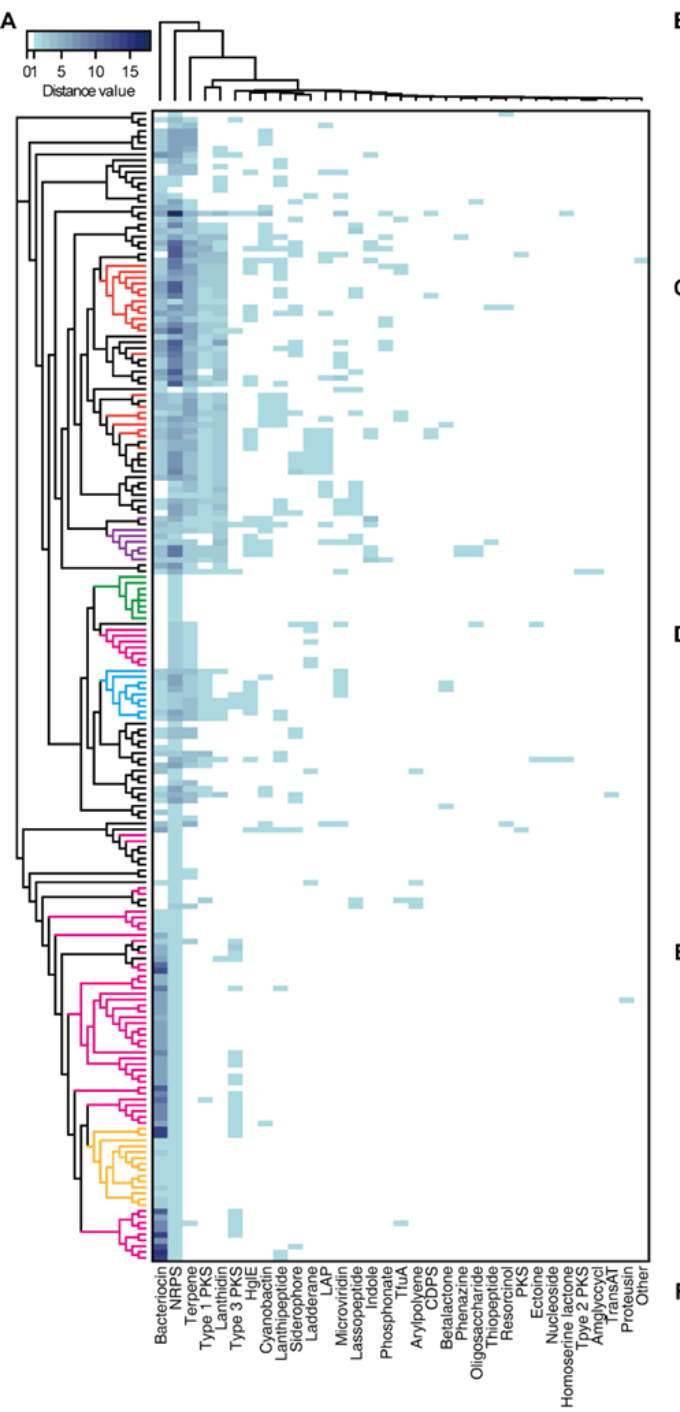

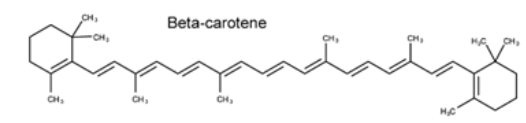

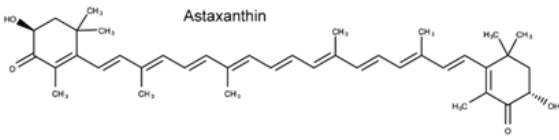

C

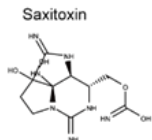

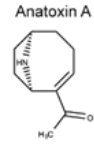
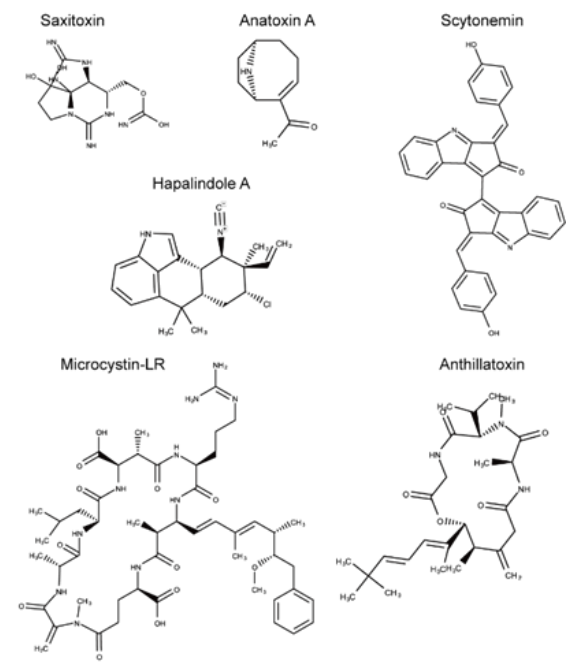

E
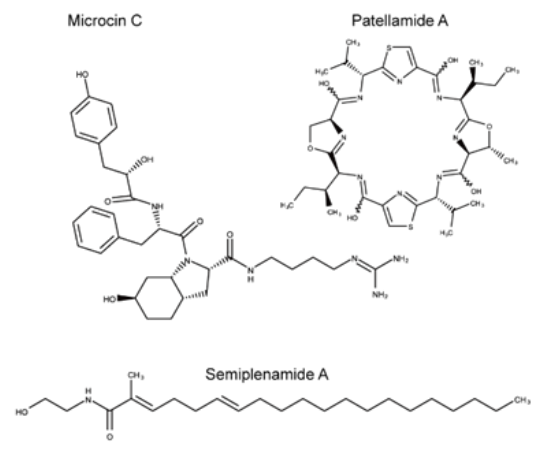

Figure 1. Cyanobacterial secondary metabolites. (A) Heatmap of the predicted cyanobacterial secondary metabolite biosynthstic gene clusters (BGCs). The left-most phylogenetic tree is constructed by up-to-date bacterial core gene (UBCG) phylogenetic analysis of the 196 cyanobacterial complete genome sequences. The evolutionary distances were provided by UBCG and plotted by RAxML $[80,81]$. The tree is not to scale. Red: Nostoc, purple: Calothrix, green: Synechocystis, pink: Synechoccus, blue: Microcystis, and yellow: Prochlorococcus. (B-F) Molecular structures of cyanobacterial secondary metabolites. (B) Terpenes, (C) alkaloids, (D) polyketides (PKs), non-ribosomal peptides (NRPs), (E) RiPPs, and (F) fatty acid amide. Abbreviations; NRPS, non-ribosomal peptide synthetase; HglE, heterocyst glycolipid synthase; LAP, linear azol(in)e-containing peptide; TfuA, ribosomally synthesized peptide antibiotic trifolitoxin; CDPS, cyclodipeptide synthase-based tRNA dependent peptide; PKS, polyketide synthase; Amglyccycl, aminoglycosides/aminocyclitols; TransAT, trans-acyltransferase type I PKS. 


\subsection{Alkaloids}

Alkaloids comprise various nitrogen containing compounds that are produced from diverse organisms, including fungi, plants, bacteria, and animals. Alkaloids produced by cyanobacteria often show toxic characteristics. For example, the anatoxin-a produced by species of the Anabaena genera is a neurotoxin that binds irreversibly to nicotinic acetylcholine receptors causing paralysis or even death in fish and mammals (Figure 1C) [31]. Anatoxin-a is also categorized as a PK, which is synthesized by PKS [82]. Another well-known example, saxitoxin, blocks the sodium $\left(\mathrm{Na}^{+}\right)$channels in shellfish and induces paralytic shellfish poisoning in humans on consumption of saxitoxin-accumulated seafood. The chemical derivatives carrying the indole rings are classified as indole alkaloids. They are biosynthesized using tryptophan as a precursor. Cyanobacterial indole alkaloids have diverse functions. For example, the hapalindole synthesized from cyanobacteria Hapalosiphon fontinalis exhibits antibacterial, anti-tuberculosis, and anticancer activities [83]. In addition, the scytonemin produced by Scytonema sp. renders photoprotective effects to the cyanobacterial cells by absorbing the harmful ultraviolet (UV)-A radiation [84].

\subsection{Polyketides/Non-Ribosomal Peptide/Lipopeptides/Siderophores}

PKS and NRPS are representatives of enzymes responsible for the biosynthesis of secondary metabolites in various organisms. Enzymes of these classes consists of at least three essential modular domains that facilitate chain elongation and modification [85]. First, the catalytic domain binds to and activates the building block, which then is transferred to the carrier protein domain. Second, the carrier protein domain loads the activated building block to the growing PK/NRP chain it holds. Third, the other catalytic domain catalyzes the bond formation between the growing chain and the newly loaded building block. PKS and NRPS differ in their use of precursors for the building block. While PKS utilizes malonyl-CoA or methylmalonyl-CoA, the NRPS uses proteinogenic and non-proteinogenic amino acid monomers. In addition, there are cases wherein compounds are synthesized via the PKS-NRPS hybrid system. A well-known example could be microcystin, the BGC of which contains two PKS, single PKS-NRPS, and three NRPS [42,86]. Microcystin produced from various cyanobacterial species belonging to the genus Microcystis, Nostoc, Planktothrix, and Anabaena, shows hepatotoxic activity in humans (Figure 1D). Various other toxins synthesized by the PKS, NRPS, or PKS-NRPS hybrid system includes lyngbyatoxin, apratoxin, and aplysiatoxin.

The NRPS includes lipopeptides owing to their lipid linked peptide structures synthesized by a combination of lipid tails and amino acids. Examples of lipopeptides include antillatoxin and carmabin from M. producens, and lyngbyabellin from M. bouillonii (Figure 1D). Antillatoxin and lyngbyabellin show neurotoxic activity and cytotoxicity, and carmabin exhibit anti-malarial activity. Siderophores are included in the NRPS-produced compounds. Iron is essential for bacterial survival. However, since it exists in an insoluble form in the environment, some bacteria have evolved to facilitate iron uptake by producing small molecules with high affinity to ferric iron, called siderophores.

\subsection{Ribosomally Synthesized and Post-Translationally Modified Peptides}

RiPP is a class of secondary metabolites that includes, as its name depicts, ribosomally synthesized and post-translationally modified peptides. Post-translational modifications include leader peptide hydrolysis, cyclization, and disulfide bond formation. RiPP BGC generally consists of a short precursor peptide with an $N$-terminal leader and a $C$-terminal core sequence, and post-translational modification (PTM) enzymes [87,88]. The PTM enzymes shape the linear peptide by several modifications that provide structural and functional diversity to the mature scaffold. Compounds that were previously classified as lanthipeptide, lasso peptide, microviridin, cyanobactin, and microcin are now re-classified under RiPP, which have a broad range of bioactivities such as protease inhibition, cytotoxicity, signaling, anti-cancer, and anti-human immunodeficiency virus (anti-HIV) (Figure 1E) [87]. For example, 
microviridin, which was first isolated from $M$. viridis, is a serine protease inhibitor, and patellamide A produced by Prochloron didemni has moderate cytotoxicity [62].

\subsection{Lipids/Saccharides/Nucleosides/Others}

Lipids, saccharides, and nucleosides are generally categorized as primary metabolites. However, there are exceptions, when they are considered as secondary metabolites instead of primary metabolites. For example, besarhanamide A and semiplenamide exhibiting toxicity against brine shrimp are fatty acid amides isolated from M. producens and Lyngbya semiplena, respectively (Figure 1F) [66,89]. It is known that cyanobacterium Cyanothece sp. 113 can produce up to $22 \mathrm{~g} / \mathrm{L}$ of polysaccharide, which exceeds the producing ability of eukaryotic microalgae, such as Dunaliella salina $[90,91]$. Polysaccharides are generally used as stabilization or thickening agents for emulsions. In some cases, they are used as bioactive compounds owing to their antitumor, antiviral, antibacterial, anti-inflammatory, and immunostimulatory properties [92-95]. Toyocamycin and tubercidin are both anti-fungal nucleoside chemicals isolated from Tolypothrix tenuis [96]. In addition, a small number of phosphonate, phenazine, ectoine, and $\beta$-lactone BGC were also detected.

\section{Engineering Cyanobacteria for Industrial Production of Secondary Metabolites}

Engineering efforts have been made to increase the production of industrially important cyanobacterial natural compounds. The model cyanobacteria such as Synechocystis sp. PCC 6803 and Synechococcus elongatus PCC 7942 are often used as engineering hosts for the increased ease of genetic manipulation. The biosynthetic pathways of other cyanobacteria are adopted to these model species by heterologous expression for production of value-added compounds. In addition to the cyanobacterial natural products, cyanobacteria have also been identified as a suitable heterologous platform for the production of biofuels, such as ethanol, butanol, and 2,3-butanediol [5,97-99]. Episomal expression using a self-replicating vector is a popular method for introducing foreign genetic elements in other organisms such as E. coli. Compared to chromosomal integration through homologous recombination, the episomal expression is more advantageous owing to its higher expression level [100]. In addition, the genome polyploidy of cyanobacteria can cause problems in the natural recombination process by reversing the engineered genome copies back to the original sequence, resulting in poor engineering efficiency and a laborious selection process. However, in cyanobacteria, there are minimal options for vector systems; the only self-replicating vector origin currently available for application is RSF1010 (Figure 2A). Thus, chromosomal integration or deletion through homologous recombination is the most dominant method used in cyanobacteria to increase the production of natural compound or heterologous metabolites (Figure 2B). Recently developed clustered regularly interspaced short palindromic repeat (CRISPR)/Cas is an effective genome engineering tool that can target specific loci to generate a double-strand break, and thus it can solve the low engineering efficiency problem in polyploids (Figure 2C) [101]. Additionally, the repurposed CRISPR/Cas system, namely the CRISPR interference (CRISPRi), can repress the gene expression without nucleic acid strand excision, avoiding lethality caused by knock-out of essential genes.

\subsection{Heterologous Expression for Cyanobacterial Secondary Metabolite Production}

Genetic manipulation tools explained above have been applied in cyanobacteria to increase the production of secondary metabolites (Table 2). In recent years, multiple studies have targeted terpenes, such as squalene and limonene. Squalene has widespread applications in the healthcare, cosmetics, and pharmacological fields, and it is produced from several eukaryotes as well as the cyanobacteria, such as Phormidium autumnale $[19,102]$. However, squalene production from cyanobacteria is not sufficient for the industrial-scale production demands. Metabolic engineering efforts were made in cyanobacterium model, S. elongatus PCC 7942 [103-105]. S. elongatus PCC 7942 has the methylerythritol phosphate (MEP) pathway to biosynthesize diphosphate (IPP) and dimethylallyl diphosphate (DMAPP) from $\mathrm{CO}_{2}$. DMAPP is converted to farnesyl diphosphate (FPP), a substrate for squalene biosynthesis, 
by FPP synthase (ispA). Heterogenous genes, including 1-deoxy-D-xylulose-5-phosphate synthase $(d x s)$, isopentenyl diphosphate isomerase (idi), and ispA were introduced into the S. elongatus PCC 7942 genome by homologous recombination to increase the intracellular concentration of FPP. Next, a squalene synthase $(S Q S)$ was also introduced by homologous recombination, resulting in a maximum of $5.0 \mathrm{mg} / \mathrm{L} / \mathrm{OD}_{730 \mathrm{~nm}}$ squalene production [103]. The titer was further increased to $12.0 \mathrm{mg} / \mathrm{L} / \mathrm{OD}_{730 \mathrm{~nm}}$ by constructing a fusion protein of $S Q S$ with $c p c B 1$, which encodes the $\beta$-subunit of phycocyanin and is highly expressed under the strong endogenous $c p c B 1$ promoter [104]. Recently, CRISPRi was applied to the squalene-producing S. elongatus PCC 7942 strain to repress two essential genes, acnB and $c p c B 2$ encoding aconitase and phycocyanin $\beta$-subunit, respectively, resulting in an improved squalene production [105]. The results of these previous studies suggest that there is sufficient potential to improve the production of target compounds in cyanobacteria through the discovery of new potent promoters or the selection of additional engineering targets.
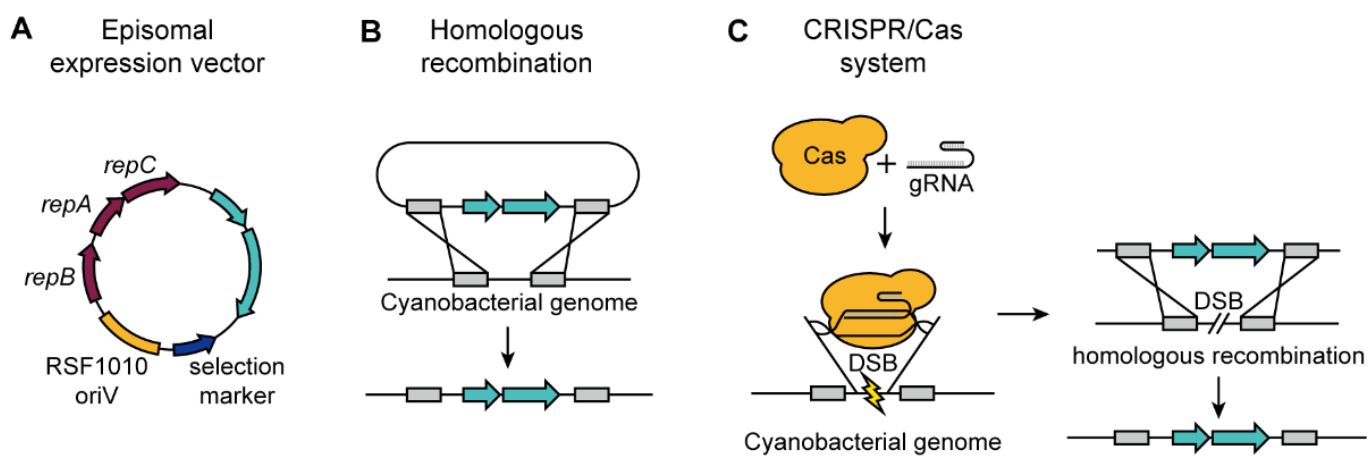

Figure 2. Genetic engineering tools. (A) Homologous recombination method using the recombination system in cyanobacteria. (B) RSF1010-derived vectors are self-replicating vectors used in episomal expression vector system. (C) CRISPR/Cas system utilizes Cas endonuclease to generate double-strand break to the gRNA-escorted loci inducing homologous recombination. Abbreviation; CRISPR, clustered regularly interspaced short palindromic repeat; gRNA, guide RNA; DSB, double-strand break.

Besides terpenes, a xanthophyll carotenoid called astaxanthin has been gaining significant attention in the healthcare field owing to the anti-inflammatory and antioxidant properties elucidated in human cells [106]. Astaxanthin production was enhanced through the engineering of Synechocystis sp. PCC 6803 [107]. First, the core biosynthetic genes, $\beta$-carotenoid ketolase $(c r t W)$ and $\beta$-carotene hydroxylase $(c r t Z)$ were integrated for astaxanthin production. The promoter combinations with diverse strength were tested for expressions of $c r t W$ and $c r t Z$, because their relative expression level is known to be critical to produce astaxanthin in E. coli [107]. However, astaxanthin production was detected only when the super-strong promoter Pcpc560 was used for both genes, indicating that other tested endogenous promoters (PnirA, PpetE, and PrnpB) were not sufficient to express those genes. To test the relative expression level of the two genes, a promoter pool with more varied strength, including the stronger promoter than Pcpc560, was required. By using Pcpc560 for crtZ expression and a pea promoter PsbA for $c r t W$ expression, which showed two-fold higher activity than Pcpc560, resulting in improved production of astaxanthin. Further, based on liquid chromatography-mass spectrometry (LC-MS) metabolomics data, fructose-1,6-/sedoheptulose 1,7-bisphosphate (FBP/SBPase), which is involved in the Calvin-Benson-Bassham cycle, was found as an additional engineering target and overexpressed with episomal expression vector. Then, heterologous $d x s$ and isp $A$ gene was introduced into Synechocystis sp. PCC 6803 genome, and the engineered strain was finally able to produce astaxanthin of $29.6 \mathrm{mg} / \mathrm{g}$ dry cell weight, the highest level in the currently known engineered strain. 
Table 2. Recent studies of engineering cyanobacteria for biochemical production.

\begin{tabular}{|c|c|c|c|c|}
\hline Strategy ${ }^{1}$ & Strain & Target $^{2}$ & Gene & Ref. \\
\hline HR & S. elongatus PCC 7942 & Isoprene & $i s p G S, i d i, d x r$ & [6] \\
\hline HR & S. elongatus PCC 7942 & Succinate * & $p p c, g l t A, k g d, g a b D$ & [108] \\
\hline HR & S. elongatus PCC 7942 & Amorpha-4,11-diene, Squalene * & $d x s$, idi, isp $A, d x r$ & [103] \\
\hline HR & S. elongatus UTEX 2973 & Sucrose * & $\csc B$ & [109] \\
\hline HR & Synechocystis sp. PCC 6803 & Isoprene & $i s p S$ & [110] \\
\hline HR & S. elongatus PCC 7942 & Isopropanol * & sadh, thl, ato $A D^{\prime}$, adc & [111] \\
\hline HR & Synechocystis sp. PCC 6803 & Geranyllinalool & $\mathrm{NaGLS}$ & [112] \\
\hline HR & S. elongatus PCC 7942 & Squalene* & $d x s, i d i$, isp $A, S Q S$ & [104] \\
\hline HR & S. elongatus PCC 7942 & Butyrate & phaBJ, Ptb, buk, pte2, tesB, yciA & [113] \\
\hline HR & Anabaena sp. PCC 7120 & Ethanol & $p d c, a d h A$, sigE, ald, inv $A B$ & [114] \\
\hline HR & S. elongatus PCC 7942 & Sucrose* & $\csc B, s p s, g l g C$ & [115] \\
\hline HR & S. elongatus PCC 7942 & 3-Hydroxybutyrate & phaAB, tesB, nphT7, pptes $B, y c i A, p t e 1$ & [116] \\
\hline HR & S. elongatus PCC 7942 & Heparosan & galU, PmHS2 & [117] \\
\hline HR & Synechocystis sp. PCC 6803 & 1-Butanol & phaAB, nphT7, fadB, phaJ, ccr, ter, pduP, mhpF, yqhD, yjgB, pk, pta, adh, sigE & [97] \\
\hline HR & Synechocystis sp. PCC 6803 & Sorbitol & s6pdh, fbp, pnt, had1, had 2 & [118] \\
\hline HR & Synechocystis sp. PCC 6803 & $\beta$-Phellandrene* & GPPS, PHLS & [119] \\
\hline HR & S. elongatus PCC 7942 & Acetone & $p d c$, ald $6, a c s, p p s, p p c, m m c$ & [120] \\
\hline HR & S. elongatus PCC 7942 & Xylitol & $x y l E F G H, X D H, D I, X R$ & [121] \\
\hline HR & S. elongatus PCC 7942 & Trehalose* & tpsp, Tret1, mts, glgCX, $\csc B$, mth & [122] \\
\hline HR & S. elongatus PCC 7942 & 2,3-Butanediol & alsD, alsS, adh, galP, zwf, edd, pgi, gnd, pfk, eda, cp12, rbcLXS, prk & [5] \\
\hline HR & S. elongatus PCC 7942 & $\alpha$-Farnesene & AFS & [123] \\
\hline HR & Synechocystis sp. PCC 6803 & Ethanol & eno, $p g k, p y k, p r k$ & [124] \\
\hline HR & S. elongatus PCC 7942 & Limonene* & $l s, G P P S, d x s$ & [125] \\
\hline HR & Synechococcus sp. PCC 7002 & D-Lactate & $\operatorname{acs} A$ & [126] \\
\hline epi & Synechocystis sp. PCC 6803 & Isoprene & ispS & [127] \\
\hline epi & Synechocystis sp. PCC 6803 & p-Hydroxyphenylacetaldoxime, dhurrin & CYP71E1, CYP79A1, UGT85B1 & [128] \\
\hline epi & Anabaena sp. PCC 7120 & Lyngbyatoxin $\mathrm{A}^{*}$ & $\operatorname{lt} x A-C, \operatorname{lt} x A-D$ & [129] \\
\hline ері & Synechocystis sp. PCC 6803 & Ethanol & $p d c, a d h, r b c S C, 70 g l p X, t k t A, f b a A$ & [98] \\
\hline epi & Synechocystis sp. PCC 6803 & Shinorine* & Fs $A B C D, A P P T$ & [130] \\
\hline epi & S. elongatus UTEX 2973 & Hapalindole* & famH1, fam H2, famH3, aph3, famE2, famD2, famC1, famC2, famC3 & [131] \\
\hline $\mathrm{HR}+$ epi & Synechocystis sp. PCC 6803 & Astaxanthin* & crtWZ, $d x s$, idi, ispA, F/SBPase, RuBisCO, rpe, tktA, psy & [107] \\
\hline $\mathrm{HR}+$ epi & S. elongatus PCC 7002 & 2,3-Butanediol & alsDS, adh & [132] \\
\hline $\mathrm{HR}+$ epi & Synechocystis sp. PCC 6803 & Isobutanol & kivd, adh & [133] \\
\hline $\mathrm{HR}+$ epi & Synechocystis sp. PCC 6803 & Limonene* & lims, rpi, rpe, GPPS & [134] \\
\hline CRISPR & S. elongatus PCC 7942 & Succinate* & $g l g C, g l t A, p p c$ & [135] \\
\hline CRISPR + epi & Synechocystis sp. PCC 6803 & Fatty alcohol * & Maqu2220, DPW, plsX, aar, ado, sll1848, sll1752, slr2060 & [136] \\
\hline CRISPR & Synechocystis sp. PCC 6803 & N-Butanol, ethanol & $\begin{array}{l}\text { adh } A, p d c, p d u P, \text { phaJ, ter, phaBCE, nphT7, sth, yqhD, xfpk, PL22, SAS2203, } \\
\text { glt } A \text {, odhB, ackA, pyrF, nrtA, ndhD }\end{array}$ & [99] \\
\hline CRISPR & S. elongatus PCC 7942 & Squalene * & $a c n B, c p c B 2$ & [105] \\
\hline
\end{tabular}

${ }^{1} \mathrm{HR}$, homologous recombination; epi, episomal expression ${ }^{2, *}$ cyanobacterial natural product. 


\subsection{Heterologous Expression for Biofuel Production}

Along with the naturally produced cyanobacterial secondary metabolites, cyanobacteria also serve as an attractive platform for diverse heterologous biochemical production. For instance, cyanobacterial genome engineering was performed to use S. elongatus PCC 7942 as a host for producing 2,3-butanediol, a biochemical building block for plasticizers, liquid fuel additives, and industrial solvents [5]. In this study, homologous recombination was used for the integration of galactose-proton symporter ( $g a l P)$, glucose-6-phosphate dehydrogenase ( $z w f)$, and 6-phosphogluconate dehydrogenase ( $g n d)$ into neutral sites, and phosphoribulokinase ( $p r k$ ) and RuBisCO subunits ( $r b c L X S$ ) into the cp12 site, resulting in a maximum production of $12.6 \mathrm{~g} / \mathrm{L}$ of 2,3-butanediol. In addition, in Synechocystis sp. PCC 6803, metabolic engineering was performed to enhance the biofuel production [99]. To improve ethanol production in the pyruvate decarboxylase $(p d c)$-inserted ethanol-producing Synechocystis sp. PCC 6803 strain, pyruvate dehydrogenase complex subunit $(o d h B)$ was repressed by CRISPRi. Repression of citrate synthase $(g l t A)$ in the phosphoketolase $(x f p k)$ and acetoacetyl-CoA synthase (nphT7)-inserted n-butanol-producing strain increased $N$-butanol production.

Isoprene is a plant-derived building block, mainly used in the manufacturing of synthetic rubber. While most of the current synthetic rubber production depends on the petrochemical source, there have been efforts made to increase the cyanobacterial production of isoprene directly from $\mathrm{CO}_{2}$. On introducing the isoprene synthase (ispS) obtained from various plants into the Synechocystis sp. PCC 6803 genome by homologous recombination, a maximum of $4.3 \mathrm{mg} / \mathrm{L} / \mathrm{h}$ isoprene production rate was achieved with the aid of $d x s$ and idi overexpression [6]. The heterologous inducible promoter Ptrc or endogenous promoters Pcpc and PpsbA2 were tested for expression of diverse ispS, and as a result, expression of Eucalyptus globulus ispS with Ptrc promoter showed the highest isoprene production. As demonstrated in various studies, cyanobacteria can produce industrially valuable biomaterials by utilizing light and $\mathrm{CO}_{2}$. Therefore, cyanobacteria have the potential to be developed into an eco-friendly and economical photoautotrophic biofactory.

\subsection{Improvement of Photosynthetic Efficiency}

The value-added biochemicals that we have discussed are all products of photosynthesis. Thus, enhancement of the photosynthetic efficiency is crucial for supplying sufficient energy and reducing power for productivity increment. Some of the strategies for improving photosynthesis include expansion of the absorption spectra to capture more light energy, downsizing of the antenna to increase high illumination tolerance, and optimization of the electron transport chain. Furthermore, efficient use of photosystem-generated energy is another strategy that can be achieved by enhancing carbon fixation or reducing carbon loss [137].

\subsection{Current Limitations in Engineering Cyanobacteria}

Until now, we have presented studies showing the potential of cyanobacteria in producing various metabolites and that continuous engineering efforts can enhance the native and non-native metabolite production from cyanobacteria. However, despite the proposed and demonstrated potential as a production host, the production levels in cyanobacteria are not compatible with those in model organisms such as E. coli or Saccharomyces cerevisiae. In the case of E. coli, which is most widely used engineering host with a lot of information about genetic features and metabolic network, it is easy to apply knowledge-based engineering approaches such as enzyme structure modification, feedback inhibition removal, and precursor pool or cofactor level increasement [138]. In addition, a high-throughput screening technique through random mutagenesis is applicable using well-developed screening systems in E. coli. On the other hand, since cyanobacteria is a photoautotroph, more complex energy generation and distribution, and redox state should be considered when manipulating the metabolic network, and thus a more systematic insight is required. Additionally, when engineering multiple targets in the metabolic pathway, it is difficult to fine-tune the relative expression levels 
of the genes due to the lack of available bioparts such as neutral site, promoter, and RBS. In order to overcome these limitations, it is essential to systematically understand the complex metabolic network within the cell and to develop various genetic tools by genome-scale screening of native promoters and RBSs or constructing synthetic bioparts. In recent studies, a systematic approach through genome-scale modeling (GEM) has been successfully applied to engineering cyanobacteria [124,125]. For more effective and efficient engineering of cyanobacteria, the systematic approach should be further advanced.

\section{Advanced Engineering Approaches through Synthetic and Systems Biology}

Synthetic biology involves development of genetic parts, combination design to fulfill the desired function, and application of the combined tool into an organism. Quantification and standardization of the genetic parts represented by promoters, RBS, untranslated region (UTR) sequences, and terminator sequences are critical for proper employment of synthetic biology. Systems biology deals with the living system as an interactive network more than just a collection of reductive components. Therefore, understanding of the organism as a system is required for precise designing of the synthetic biology tools, and the introduction of synthetic biology tools into an organism affects the system, making the two biological approaches inseparable. The general synthetic and systems biology research flow is represented as the design-build-test-learn cycle (Figure 3). In the design step, the host for metabolite production is selected, and the biosynthesis pathway is designed using prior knowledge. Then, in the build step, a bioproduction host is engineered using either random, rational, or both methods. The constructed strain may undergo various tests for data generation. The data are then analyzed to produce and update the understanding of the bioproduction system. Systems and synthetic biology as an integrative approach, assisted the engineering of various organisms, including cyanobacteria.

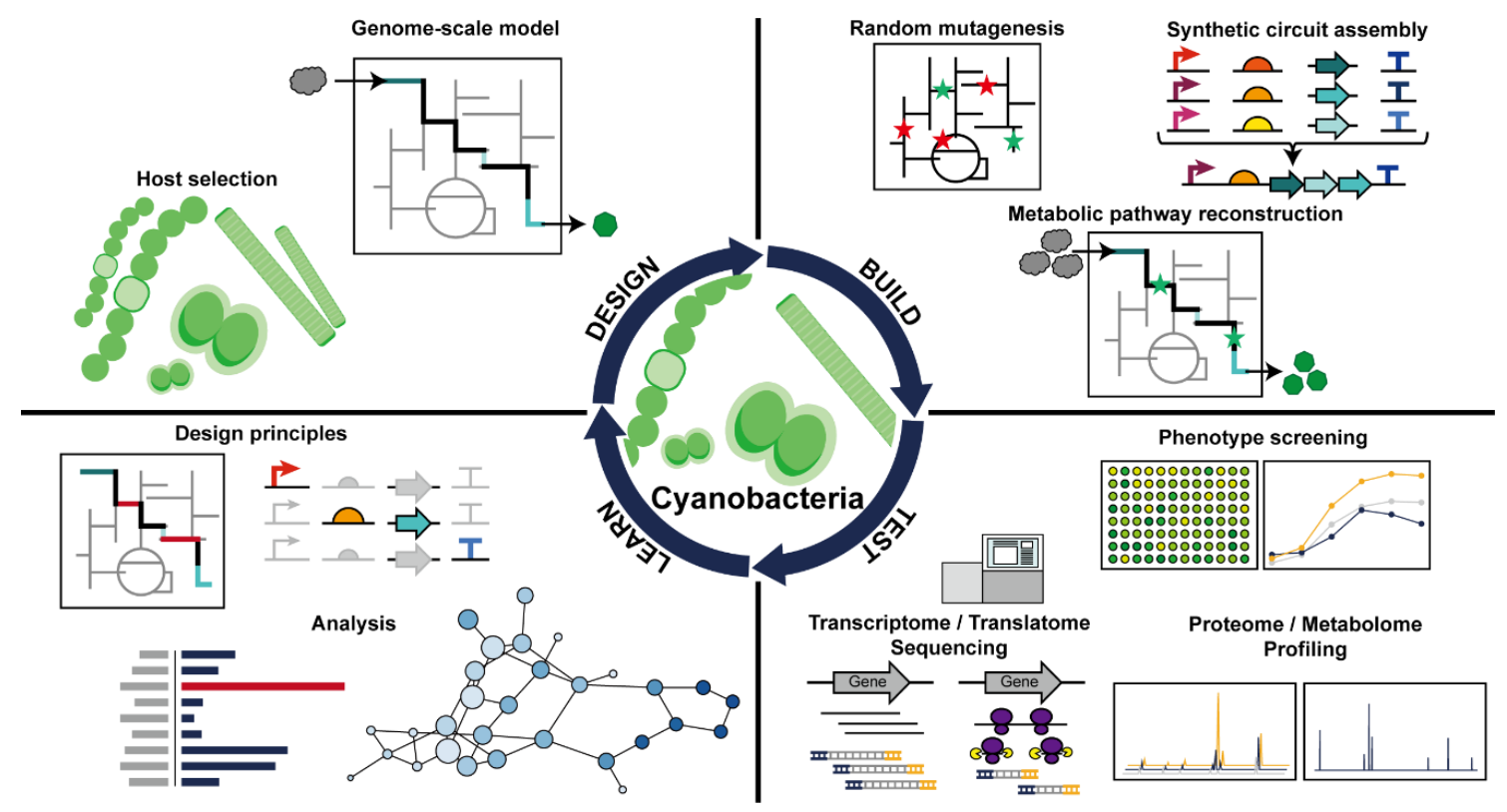

Figure 3. Schematic representation of design-build-test-learn cycle in cyanobacteria.

\subsection{Synthetic Biology}

Development of the genetic parts is critical for applying synthetic biology to metabolic engineering of cyanobacteria. While in other model species (e.g., E. coli), genetic parts such as promoters and RBS with varying strengths are available, there has been a significant lack of information and diversity concerning the cyanobacterial genetic parts. Currently used genetic parts are cyanobacterial endogenous promoters $\left(\mathrm{P}_{\mathrm{psbA}}\right.$ and $\left.\mathrm{P}_{\mathrm{cpc}}\right)$ and E. coli origin promoters $\left(\mathrm{P}_{\text {trc }}, \mathrm{P}_{\mathrm{BAD}}, \mathrm{P}_{\text {lac }}\right.$, and $\left.\mathrm{P}_{\text {nrs }}\right)$ [139]. Promoters 
currently used in cyanobacteria are cataloged in previous literature [140]. However, to expand the promoter selection pool, several $\mathrm{P}_{\mathrm{T} 7}$ derivatives, $\mathrm{P}_{\mathrm{psbA}}$ * derivatives, $\mathrm{P}_{\mathrm{trc}}$-based hybrid, and synthetic promoters have been developed and tested in Synechocystis sp. PCC 6803 [141,142]. Recently, a mutant promoter library from two popular promoters, $\mathrm{P}_{\mathrm{psbA}}$ and $\mathrm{P}_{\mathrm{cpc}}$ of $S$. elongatus PCC 7942, were generated to achieve promoters of varying strength [143]. A collection of 48 unique promoters were validated in three additional S. elongatus strains, expanding the cyanobacterial synthetic biology toolbox. The RBSs for cyanobacterial gene expression are mostly wild-type RBS associated with native promoter, or RBS of highly expressed genes such as $p s b A 2$ and $r b c L$ [144]. In addition, synthetic RBSs from BioBrick Registry of standard biological parts, and a newly designed RBS based on Synechocystis sp. PCC 6803 genome sequence (RBS*) are also used in several studies [145]. Recently, research has been conducted to diversify the RBS types used in cyanobacterial engineering. Twenty types of native RBS from Synechocystis sp. PCC 6803 were additionally identified, and 13 RBSs were rationally designed based on the known strong RBS sequences [142,146].

Riboswitches are another class of bioparts operated based on their RNA structures. A riboswitch comprises of an aptamer and an expression part. While the aptamer directly binds to a corresponding small molecule, the expression part regulates gene expression post-transcriptionally by causing structural changes in accordance with the small molecule binding. In S. elongatus PCC 7942, the operation of the synthetic theophylline riboswitch confirmed that it could control translation initiation [147]. Recently, this riboswitch was applied for flexible regulation of intracellular glycogen storage by controlling the expression of ADP-glucose pyrophosphorylase (glgC) [148]. The theophylline riboswitch was found to be operational in several other cyanobacterial species, including Leptolyngbya sp. BL 0902, Nostoc sp. 7120, and Synechocystis sp. WHSyn [149]. The theophylline riboswitch has also been used for chimeric riboswitch generation by combining it with a Bacillus subtilis phuE (adenine riboswitch). The chimeric riboswitch was validated in Nostoc sp. 7120 [150]. Overall, various synthetic biology toolboxes applicable to cyanobacteria are being developed to expand the pool of choice, which would contribute to effective engineering by enabling precise gene regulation of cyanobacteria.

\subsection{Next-Generation Sequencing/Omics/Genome-Scale Model}

Approximately 1500 cyanobacterial genome sequences have been registered in the NCBI genome database, and 196 of them, including the genome sequences of Synechocystis sp. PCC 6803 and S. elongatus PCC 7942, are completely assembled. In particular, the complete genome sequence of Synechocystis sp. PCC 6803 was reported as early as E. coli genome sequence, thus settling as a model organism among cyanobacteria [151]. Since then, with the development of diverse next-generation sequencing (NGS) techniques, various omics data such as transcriptome and translatome were generated based on the genome sequence [9]. Previously, transcriptome changes in response to stress conditions, such as temperature, light, and nutrition depletion, and effects of gene deletions were analyzed using cyanobacterium models, including Synechocystis sp. PCC 6803, S. elongatus PCC 7942, and Nostoc sp. 7120 [9]. In addition to the model cyanobacteria, recent transcriptome studies are being conducted in various non-model cyanobacterium species as well (Table 3). For example, in Euhalothece living in a hypersaline habitat, various salt resistance-related genes, such as $\mathrm{Na}^{+}$ transporting multiple resistance and $\mathrm{pH}$ adaptation systems, and glycine betaine biosynthesis enzymes were highly upregulated [152]. In addition, differential RNA-seq revealed genome-wide transcription start sites (TSSs) in S. elongatus UTEX 2973 and two types of Fischerella strains, which were used to elucidate the differences in transcriptional regulation resulting in different phenotypes $[153,154]$. Additionally, the application of Ribo-seq to observe the translatome responses of Synechocystis sp. PCC 6803 under carbon starvation condition was reported in 2018 [155]. In order to observe the post-transcriptional responses in cyanobacteria, omics studies such as proteomics through liquid chromatography with tandem mass spectrometry (LC-MS/MS) analysis and metabolomics through gas chromatography-mass spectrometry (GC-MS) and ${ }^{13} \mathrm{C}$ isotopically nonstationary metabolic flux analysis have been implemented $[5,156]$. The massive omics data generated from the sequencing 
techniques described above served as the basis for understanding the cyanobacterial system under various conditions and also aided in the development of cyanobacterial GEMs.

GEM is an in silico tool that is useful for explaining the entire metabolism of an organism based on its genomic information. Given the ability to predict cellular metabolic behavior under given conditions or constraints, GEMs are mainly used for designing metabolic engineering strategies. GEM is an iteratively evolving system mended by new input information starting from the prior draft. Thus, more precise GEMs can be constructed by gathering greater types and amounts of genome information. GEM has been witnessing significant advancements with continuous accumulation of massive omics data supplied by various NGS techniques. Among cyanobacteria, Synechocystis sp. PCC 6803 has been studied most extensively, starting with the central carbon metabolic reconstruction under heterotrophic, mixotrophic, or autotrophic conditions $[157,158]$. The Synechocystis sp. PCC 6803 GEM was recently updated with more detailed photosynthesis and electron transport chain data $[159,160]$. GEM of other cyanobacterial species, such as Arthrospira platensis, Cyanothece sp., Nostoc sp., S. elongatus UTEX 2973, S. elongatus PCC 7942, and Synechococcus sp., are being established and further enhanced [139]. Through in silico GEM simulation, the bottleneck step can be selected for optimal engineering to enhance the production of value-added biochemicals. In the near future, the continuously evolving GEM would grow more useful in the metabolic engineering of cyanobacteria.

Table 3. Recent advances in omics studies of cyanobacteria.

\begin{tabular}{cllc}
\hline Year & \multicolumn{1}{c}{ Omics Study } & \multicolumn{1}{c}{ Strain } & Ref. \\
\hline 2016 & Genome-scale model (GEM) + Metabolome & Synechococcus sp. PCC 7002 & {$[161]$} \\
2016 & Metabolome & S. elongatus PCC 7942 & {$[6]$} \\
2016 & Metabolome + Transcriptome & Synechocystis sp. PCC 6803 & {$[127]$} \\
2016 & Proteome & S. elongatus PCC 7942 & {$[162]$} \\
2016 & Proteome & Synechocystis sp. PCC 6803 & {$[163]$} \\
2016 & Transcriptome & S. elongatus PCC 7942 & {$[164]$} \\
2016 & Transcriptome & Synechocystis sp. PCC 6803 & {$[165]$} \\
2016 & Transcriptome & Prochlorococcus NATL2A & {$[166]$} \\
2016 & Transcriptome & Nostoc sp. PCC 7120 & {$[167]$} \\
2016 & Transcriptome & S. elongatus PCC 7942 & {$[168]$} \\
2016 & GEM & S. elongatus PCC 7942 & {$[10]$} \\
2016 & Transcriptome & M. aeruginosa & {$[169]$} \\
2017 & Metabolome & Synechococcus sp. PCC 7002 & {$[170]$} \\
2017 & Metabolome & S. elongatus PCC 7942 & {$[171]$} \\
2017 & Metabolome & S. elongatus PCC 7942 & {$[172]$} \\
2017 & Metabolome & S. elongatus PCC 7942 & {$[5]$} \\
2017 & Metabolome & Synechocystis sp. PCC 6803 & {$[173]$} \\
2017 & Proteome & Synechocystis sp. PCC 6803 & {$[174]$} \\
2017 & Proteome & Synechocystis sp. PCC 6803 & {$[175]$} \\
2017 & Proteome & Synechocystis sp. PCC 6803 & {$[176]$} \\
2017 & Proteome & Synechococcus strains & {$[177]$} \\
2017 & Proteome & Prochlorococcus strains & {$[178]$} \\
2017 & Proteome & P. marinus SS 120 & {$[179]$} \\
2017 & Proteome & Synechocystis sp. PCC 6803 & {$[180]$} \\
2017 & Transcriptome & Synechocystis sp. PCC 6803 & {$[181]$} \\
2017 & Transcriptome + Interactome & Synechocystis sp. PCC 6803 & {$[182]$} \\
2017 & Transcriptome + Metabolome & Synechococcus sp. IU 625 & {$[183]$} \\
2017 & Transcription start site (TSS) & F. muscicola PCC 7414 and F. thermalis PCC 7521 & {$[154]$} \\
2017 & GEM & Synechocystis sp. PCC 6803 & {$[184]$} \\
2017 & GEM & Nostoc sp. PCC 7120 & {$[185]$} \\
2017 & GEM & S. elongatus UTEX 2973 & {$[186]$} \\
2017 & GEM & Synechococcus sp. PCC 7002 & {$[161]$} \\
2018 & Transcriptome & M. aeruginosa & {$[187]$} \\
2018 & Transcriptome + Translatome & Synechocystis sp. PCC 6803 & {$[155]$} \\
2018 & TSS & S. elongatus UTEX 2973 & {$[153]$} \\
2018 & GEM & Synechocystis sp. PCC 6803 & {$[161]$} \\
\hline & & & \\
\end{tabular}


Table 3. Cont.

\begin{tabular}{|c|c|c|c|}
\hline Year & Omics Study & Strain & Ref. \\
\hline 2019 & Metabolome & Synechococcus sp. PCC 7002 & [188] \\
\hline 2019 & Proteome & Synechocystis sp. PCC 6803 & [189] \\
\hline 2019 & Transcriptome & Prochlorococcus MIT9313 & [190] \\
\hline 2019 & Transcriptome & N. punctiforme PCC 73102 & [191] \\
\hline 2019 & Transcriptome & Leptolyngbya sp. PCC 6406 & [192] \\
\hline 2020 & GEM & Synechocystis sp. PCC 6803 & {$[160]$} \\
\hline 2020 & Metabolome & S. elongatus PCC 11802 and PCC 11801 & [193] \\
\hline 2020 & Metabolome & Nostoc sp. UIC 10630 & [194] \\
\hline 2020 & Metabolome & Leibleinia gracilis & [195] \\
\hline 2020 & Metabolome & Synechocystis sp. PCC 6803 & [196] \\
\hline 2020 & Metabolome & S. elongatus UTEX 2973 & [197] \\
\hline 2020 & Metabolome & S. elongatus PCC 11801 & [198] \\
\hline 2020 & Metabolome & M. aeruginosa PCC 7820 and PCC 7806 & [199] \\
\hline 2020 & Metabolome & Synechocystis sp. PCC 6803 & [200] \\
\hline 2020 & Metabolome & Nodularia spumigena & [201] \\
\hline 2020 & Proteome & Nostoc sp. PCC 7120 & [202] \\
\hline 2020 & Proteome & Synechococcus strains & [203] \\
\hline 2020 & Proteome & Nodosilinea strains & [204] \\
\hline 2020 & Transcriptome & Nostoc sp. PCC 7120 & [205] \\
\hline 2020 & Transcriptome & Euhalothece sp. Z-M001 & [152] \\
\hline 2020 & Transcriptome & Synechocystis sp. PCC 6803 & [206] \\
\hline 2020 & Transcriptome & N. punctiforme PCC 73102 & [207] \\
\hline 2020 & Transcriptome & Synechococcus sp. PCC 7002 & [208] \\
\hline 2020 & Transcriptome + Metabolome & Synechocystis sp. PCC 6803 & {$[107]$} \\
\hline 2020 & GEM & Synechococcus sp. BDU 130192 & [209] \\
\hline 2020 & GEM & A. variabilis ATCC 29413 & [210] \\
\hline
\end{tabular}

\section{Conclusions and Future Perspectives}

Cyanobacteria have significant industrial value owing to their ability to generate energy from photosynthesis and to produce various secondary metabolites. However, several improvements are required for cyanobacteria to meet the industry-level expectations and to establish themselves as a potential bioproduction platform. First, when using cyanobacterial native promoter or RBS, unexpected interaction may occur within the cell, which may reduce engineering efficiency. Therefore, development and application of the variety of orthogonal tools for engineering cyanobacteria is crucial. In addition, it is essential to obtain the precise metabolic network information to design strategies for the concise use of the synthetic biology tools. For example, the optimal production conditions can be discovered through promoter and RBS combination randomization, and the kind of neutral sites that can be used for chromosome integration can be expanded based on essential gene information found with transposon mutagenesis $[143,146,211,212]$. In addition, by applying the rapidly developing CRISPR application, it is possible to repress or activate multiple target genes at once, which can shorten the laborious and tedious engineering process caused by the polyploidy genome characteristic of cyanobacteria [101]. Systems biology enabled the discovery of various genetic tools by generating and accumulating massive omics data in cyanobacteria. In addition, development of GEM based on the accumulating omics and experimental data would lead to the development of a more accurate metabolic model.

Author Contributions: Conceptualization, Y.J., S.C. and B.-K.C.; writing-original draft preparation, Y.J., S.-H.C., S.C. and B.-K.C.; writing-review and editing, H.L., H.-K.C., D.-M.K., C.-G.L. and B.-K.C.; visualization, Y.J., S.-H.C. and S.C.; supervision, S.C. and B.-K.C.; project administration, S.C. and B.-K.C.; funding acquisition, S.C. and B.-K.C. All authors have read and agreed to the published version of the manuscript.

Funding: This research was funded by the Basic Core Technology Development Program for the Oceans and the Polar Regions of the National Research Foundation (NRF), funded by the Ministry of Science and ICT of Korea, grant numbers NRF-2016M1A5A1027458 and NRF-2016M1A5A1027455. The APC was funded by NRF-2016M1A5A1027458.

Conflicts of Interest: The authors declare no conflict of interest. 


\section{References}

1. Singh, J.S.; Kumar, A.; Rai, A.N.; Singh, D.P. Cyanobacteria: A precious bio-resource in agriculture, ecosystem, and environmental sustainability. Front. Microbiol. 2016, 7, 529. [CrossRef] [PubMed]

2. Mogany, T.; Swalaha, F.M.; Kumari, S.; Bux, F. Elucidating the role of nutrients in C-phycocyanin production by the halophilic cyanobacterium Euhalothece sp. J. Appl. Phycol. 2018, 30, 2259-2271. [CrossRef]

3. Liang, C.; Zhao, F.; Wei, W.; Wen, Z.; Qin, S. Carotenoid biosynthesis in cyanobacteria: Structural and evolutionary scenarios based on comparative genomics. Int. J. Biol. Sci. 2006, 2, 197. [CrossRef] [PubMed]

4. Lee, H.J.; Lee, J.; Lee, S.-M.; Um, Y.; Kim, Y.; Sim, S.J.; Choi, J.-I.; Woo, H.M. Direct conversion of CO2 to $\alpha$-farnesene using metabolically engineered Synechococcus elongatus PCC 7942. J. Agric. Food Chem. 2017, 65, 10424-10428. [CrossRef]

5. Kanno, M.; Carroll, A.L.; Atsumi, S. Global metabolic rewiring for improved $\mathrm{CO}_{2}$ fixation and chemical production in cyanobacteria. Nat. Commun. 2017, 8, 14724. [CrossRef]

6. Gao, X.; Gao, F.; Liu, D.; Zhang, H.; Nie, X.; Yang, C. Engineering the methylerythritol phosphate pathway in cyanobacteria for photosynthetic isoprene production from $\mathrm{CO}_{2}$. Energy Environ. Sci. 2016, 9, 1400-1411. [CrossRef]

7. Stephanopoulos, G. Synthetic biology and metabolic engineering. ACS Synth. Biol. 2012, 1, 514-525. [CrossRef]

8. Ramey, C.J.; Barón-Sola, A.N.; Aucoin, H.R.; Boyle, N.R. Genome engineering in cyanobacteria: Where we are and where we need to go. ACS Synth. Biol. 2015, 4, 1186-1196. [CrossRef]

9. Lin, W.-R.; Tan, S.-I.; Hsiang, C.-C.; Sung, P.-K.; Ng, I.-S. Challenges and opportunity of recent genome editing and multi-omics in cyanobacteria and microalgae for biorefinery. Bioresour. Technol. 2019, 291, 121932. [CrossRef]

10. Broddrick, J.T.; Rubin, B.E.; Welkie, D.G.; Du, N.; Mih, N.; Diamond, S.; Lee, J.J.; Golden, S.S.; Palsson, B.O. Unique attributes of cyanobacterial metabolism revealed by improved genome-scale metabolic modeling and essential gene analysis. Proc. Natl. Acad. Sci. USA 2016, 113, E8344-E8353. [CrossRef]

11. Kultschar, B.; Llewellyn, C. Secondary metabolites in cyanobacteria. In Secondary Metabolites-Sources and Applications; IntechOpen: London, UK, 2018; pp. 23-36.

12. Romay, C.; Armesto, J.; Remirez, D.; Gonzalez, R.; Ledon, N.; Garcia, I. Antioxidant and anti-inflammatory properties of C-phycocyanin from blue-green algae. Inflamm. Res. 1998, 47, 36-41. [CrossRef] [PubMed]

13. Romay, C.; Gonzalez, R.; Ledon, N.; Remirez, D.; Rimbau, V. C-phycocyanin: A biliprotein with antioxidant, anti-inflammatory and neuroprotective effects. Curr. Protein Pept. Sci. 2003, 4, 207-216. [CrossRef] [PubMed]

14. Benedetti, S.; Benvenuti, F.; Pagliarani, S.; Francogli, S.; Scoglio, S.; Canestrari, F. Antioxidant properties of a novel phycocyanin extract from the blue-green alga Aphanizomenon flos-aquae. Life Sci. 2004, 75, 2353-2362. [CrossRef] [PubMed]

15. Kuddus, M.; Singh, P.; Thomas, G.; Al-Hazimi, A. Recent developments in production and biotechnological applications of C-phycocyanin. BioMed Res. Int. 2013, 2013, 742859. [CrossRef]

16. Patel, A.; Mishra, S.; Ghosh, P.K. Antioxidant potential of C-phycocyanin isolated from cyanobacterial species Lyngbya, Phormidium and Spirulina spp. Indian J. Biochem. Biophys. 2006, 43, 25-31.

17. Stahl, W.; Sies, H. Antioxidant activity of carotenoids. Mol. Asp. Med. 2003, 24, 345-351. [CrossRef]

18. Wada, N.; Sakamoto, T.; Matsugo, S. Multiple roles of photosynthetic and sunscreen pigments in cyanobacteria focusing on the oxidative stress. Metabolites 2013, 3, 463-483. [CrossRef]

19. Fagundes, M.B.; Falk, R.B.; Facchi, M.M.X.; Vendruscolo, R.G.; Maroneze, M.M.; Zepka, L.Q.; Jacob-Lopes, E.; Wagner, R. Insights in cyanobacteria lipidomics: A sterols characterization from Phormidium autumnale biomass in heterotrophic cultivation. Food Res. Int. 2019, 119, 777-784. [CrossRef]

20. Kellmann, R.; Mihali, T.K.; Neilan, B.A. Identification of a saxitoxin biosynthesis gene with a history of frequent horizontal gene transfers. J. Mol. Evol. 2008, 67, 526-538. [CrossRef]

21. Mihali, T.K.; Kellmann, R.; Neilan, B.A. Characterisation of the paralytic shellfish toxin biosynthesis gene clusters in Anabaena circinalis AWQC131C and Aphanizomenon sp. NH-5. BMC Biochem. 2009, 10, 8. [CrossRef]

22. Murray, S.A.; Wiese, M.; Stuken, A.; Brett, S.; Kellmann, R.; Hallegraeff, G.; Neilan, B.A. sxtA-based quantitative molecular assay to identify saxitoxin-producing harmful algal blooms in marine waters. Appl. Environ. Microbiol. 2011, 77, 7050-7057. [CrossRef] [PubMed] 
23. Burja, A.M.; Banaigs, B.; Abou-Mansour, E.; Burgess, J.G.; Wright, P.C.J.T. Marine cyanobacteria-A prolific source of natural products. Tetrahedron 2001, 57, 9347-9377. [CrossRef]

24. Rastogi, R.P.; Sonani, R.R.; Madamwar, D. Cyanobacterial sunscreen scytonemin: Role in photoprotection and biomedical research. Appl. Biochem. Biotechnol. 2015, 176, 1551-1563. [CrossRef] [PubMed]

25. Garcia-Pichel, F.; Castenholz, R.W.J.J.O.P. Characterization and biological implications of scytonemin, a cyanobacterial sheath pigment. J. Phycol. 1991, 27, 395-409. [CrossRef]

26. Proteau, P.J.; Gerwick, W.H.; Garcia-Pichel, F.; Castenholz, R. The structure of scytonemin, an ultraviolet sunscreen pigment from the sheaths of cyanobacteria. Experientia 1993, 49, 825-829. [CrossRef] [PubMed]

27. Soule, T.; Stout, V.; Swingley, W.D.; Meeks, J.C.; Garcia-Pichel, F. Molecular genetics and genomic analysis of scytonemin biosynthesis in Nostoc punctiforme ATCC 29133. J. Bacteriol. 2007, 189, 4465-4472. [CrossRef] [PubMed]

28. Klein, D.; Daloze, D.; Braekman, J.C.; Hoffmann, L.; Demoulin, V. New hapalindoles from the cyanophyte Hapalosiphon laingii. J. Nat. Prod. 1995, 58, 1781-1785. [CrossRef]

29. Moore, R.E.; Cheuk, C.; Patterson, G.M.L. Hapalindoles: New alkaloids from the blue-green alga Hapalosiphon fontinalis. J. Am. Chem. Soc. 1984, 106, 6456-6457. [CrossRef]

30. Mejean, A.; Mann, S.; Maldiney, T.; Vassiliadis, G.; Lequin, O.; Ploux, O. Evidence that biosynthesis of the neurotoxic alkaloids anatoxin-a and homoanatoxin-a in the cyanobacterium Oscillatoria PCC 6506 occurs on a modular polyketide synthase initiated by L-proline. J. Am. Chem. Soc. 2009, 131, 7512-7513. [CrossRef] [PubMed]

31. Rantala-Ylinen, A.; Kana, S.; Wang, H.; Rouhiainen, L.; Wahlsten, M.; Rizzi, E.; Berg, K.; Gugger, M.; Sivonen, K. Anatoxin-a synthetase gene cluster of the cyanobacterium Anabaena sp. strain 37 and molecular methods to detect potential producers. Appl. Environ. Microbiol. 2011, 77, 7271-7278. [CrossRef]

32. Moore, R.E.; Blackman, A.J.; Cheuk, C.E.; Mynderse, J.S.; Matsumoto, G.K.; Clardy, J.; Woodard, R.W.; Craig, J.C. Absolute stereochemistries of the aplysiatoxins and oscillatoxin A. J. Org. Chem. 1984, 49, 2484-2489. [CrossRef]

33. Gupta, D.K.; Kaur, P.; Leong, S.T.; Tan, L.T.; Prinsep, M.R.; Chu, J.J. Anti-Chikungunya viral activities of aplysiatoxin-related compounds from the marine cyanobacterium Trichodesmium erythraeum. Mar. Drugs 2014, 12, 115-127. [CrossRef] [PubMed]

34. Edwards, D.J.; Gerwick, W.H. Lyngbyatoxin biosynthesis: Sequence of biosynthetic gene cluster and identification of a novel aromatic prenyltransferase. J. Am. Chem. Soc. 2004, 126, 11432-11433. [CrossRef] [PubMed]

35. Mihali, T.K.; Kellmann, R.; Muenchhoff, J.; Barrow, K.D.; Neilan, B.A. Characterization of the gene cluster responsible for cylindrospermopsin biosynthesis. Appl. Environ. Microbiol. 2008, 74, 716-722. [CrossRef]

36. Stuken, A.; Jakobsen, K.S. The cylindrospermopsin gene cluster of Aphanizomenon sp. strain 10E6: Organization and recombination. Microbiology (Reading) 2010, 156, 2438-2451. [CrossRef] [PubMed]

37. Mazmouz, R.; Chapuis-Hugon, F.; Mann, S.; Pichon, V.; Mejean, A.; Ploux, O. Biosynthesis of cylindrospermopsin and 7-epicylindrospermopsin in Oscillatoria sp. strain PCC 6506: Identification of the cyr gene cluster and toxin analysis. Appl. Environ. Microbiol. 2010, 76, 4943-4949. [CrossRef] [PubMed]

38. Gross, E.M.; Wolk, C.P.; Jüttner, F. Fischerellin, a new allelochemical from the freshwater cyanobacterium Fischerella Muscicola. J. Phycol. 1991, 27, 686-692. [CrossRef]

39. Cox, P.A.; Banack, S.A.; Murch, S.J.; Rasmussen, U.; Tien, G.; Bidigare, R.R.; Metcalf, J.S.; Morrison, L.F.; Codd, G.A.; Bergman, B. Diverse taxa of cyanobacteria produce $\beta-\mathrm{N}$-methylamino-L-alanine, a neurotoxic amino acid. Proc. Natl. Acad. Sci. USA 2005, 102, 5074-5078. [CrossRef]

40. Rounge, T.B.; Rohrlack, T.; Nederbragt, A.J.; Kristensen, T.; Jakobsen, K.S. A genome-wide analysis of nonribosomal peptide synthetase gene clusters and their peptides in a Planktothrix rubescens strain. BMC Genom. 2009, 10, 396. [CrossRef]

41. Tooming-Klunderud, A.; Rohrlack, T.; Shalchian-Tabrizi, K.; Kristensen, T.; Jakobsen, K.S. Structural analysis of a non-ribosomal halogenated cyclic peptide and its putative operon from Microcystis: Implications for evolution of cyanopeptolins. Microbiology (Reading) 2007, 153, 1382-1393. [CrossRef] [PubMed]

42. Tillett, D.; Dittmann, E.; Erhard, M.; von Dohren, H.; Borner, T.; Neilan, B.A. Structural organization of microcystin biosynthesis in Microcystis aeruginosa PCC7806: An integrated peptide-polyketide synthetase system. Chem. Biol. 2000, 7, 753-764. [CrossRef] 
43. Kaneko, T.; Nakajima, N.; Okamoto, S.; Suzuki, I.; Tanabe, Y.; Tamaoki, M.; Nakamura, Y.; Kasai, F.; Watanabe, A.; Kawashima, K.; et al. Complete genomic structure of the bloom-forming toxic cyanobacterium Microcystis aeruginosa NIES-843. DNA Res. 2007, 14, 247-256. [CrossRef] [PubMed]

44. Rouhiainen, L.; Vakkilainen, T.; Siemer, B.L.; Buikema, W.; Haselkorn, R.; Sivonen, K. Genes coding for hepatotoxic heptapeptides (microcystins) in the cyanobacterium Anabaena strain 90. Appl. Environ. Microbiol. 2004, 70, 686-692. [CrossRef] [PubMed]

45. Christiansen, G.; Fastner, J.; Erhard, M.; Borner, T.; Dittmann, E. Microcystin biosynthesis in planktothrix: Genes, evolution, and manipulation. J. Bacteriol. 2003, 185, 564-572. [CrossRef]

46. Moffitt, M.C.; Neilan, B.A. Characterization of the nodularin synthetase gene cluster and proposed theory of the evolution of cyanobacterial hepatotoxins. Appl. Environ. Microbiol. 2004, 70, 6353-6362. [CrossRef]

47. Grindberg, R.V.; Ishoey, T.; Brinza, D.; Esquenazi, E.; Coates, R.C.; Liu, W.T.; Gerwick, L.; Dorrestein, P.C.; Pevzner, P.; Lasken, R.; et al. Single cell genome amplification accelerates identification of the apratoxin biosynthetic pathway from a complex microbial assemblage. PLoS ONE 2011, 6, e18565. [CrossRef]

48. Ishida, K.; Christiansen, G.; Yoshida, W.Y.; Kurmayer, R.; Welker, M.; Valls, N.; Bonjoch, J.; Hertweck, C.; Borner, T.; Hemscheidt, T.; et al. Biosynthesis and structure of aeruginoside 126A and 126B, cyanobacterial peptide glycosides bearing a 2-carboxy-6-hydroxyoctahydroindole moiety. Chem. Biol. 2007, 14, 565-576. [CrossRef]

49. Ishida, K.; Welker, M.; Christiansen, G.; Cadel-Six, S.; Bouchier, C.; Dittmann, E.; Hertweck, C.; Tandeau de Marsac, N. Plasticity and evolution of aeruginosin biosynthesis in cyanobacteria. Appl. Environ. Microbiol. 2009, 75, 2017-2026. [CrossRef]

50. Magarvey, N.A.; Beck, Z.Q.; Golakoti, T.; Ding, Y.; Huber, U.; Hemscheidt, T.K.; Abelson, D.; Moore, R.E.; Sherman, D.H. Biosynthetic characterization and chemoenzymatic assembly of the cryptophycins. Potent anticancer agents from cyanobionts. ACS Chem. Biol. 2006, 1, 766-779. [CrossRef]

51. Fewer, D.P.; Osterholm, J.; Rouhiainen, L.; Jokela, J.; Wahlsten, M.; Sivonen, K. Nostophycin biosynthesis is directed by a hybrid polyketide synthase-nonribosomal peptide synthetase in the toxic cyanobacterium Nostoc sp. strain 152. Appl. Environ. Microbiol. 2011, 77, 8034-8040. [CrossRef]

52. Chang, Z.; Sitachitta, N.; Rossi, J.V.; Roberts, M.A.; Flatt, P.M.; Jia, J.; Sherman, D.H.; Gerwick, W.H. Biosynthetic pathway and gene cluster analysis of curacin A, an antitubulin natural product from the tropical marine cyanobacterium Lyngbya majuscula. J. Nat. Prod. 2004, 67, 1356-1367. [CrossRef] [PubMed]

53. Ramaswamy, A.V.; Sorrels, C.M.; Gerwick, W.H. Cloning and biochemical characterization of the hectochlorin biosynthetic gene cluster from the marine cyanobacterium Lyngbya majuscula. J. Nat. Prod. 2007, 70, 1977-1986. [CrossRef]

54. Edwards, D.J.; Marquez, B.L.; Nogle, L.M.; McPhail, K.; Goeger, D.E.; Roberts, M.A.; Gerwick, W.H. Structure and biosynthesis of the jamaicamides, new mixed polyketide-peptide neurotoxins from the marine cyanobacterium Lyngbya majuscula. Chem. Biol. 2004, 11, 817-833. [CrossRef] [PubMed]

55. Nogle, L.M.; Williamson, R.T.; Gerwick, W.H. Somamides A and B, two new depsipeptide analogues of dolastatin 13 from a Fijian cyanobacterial assemblage of Lyngbya majuscula and Schizothrix species. J. Nat. Prod. 2001, 64, 716-719. [CrossRef] [PubMed]

56. Nogle, L.M.; Gerwick, W.H. Isolation of four new cyclic depsipeptides, antanapeptins A-D, and dolastatin 16 from a Madagascan collection of Lyngbya majuscula. J. Nat. Prod. 2002, 65, 21-24. [CrossRef]

57. Berman, F.W.; Gerwick, W.H.; Murray, T.F. Antillatoxin and kalkitoxin, ichthyotoxins from the tropical cyanobacterium Lyngbya majuscula, induce distinct temporal patterns of NMDA receptor-mediated neurotoxicity. Toxicon 1999, 37, 1645-1648. [CrossRef]

58. McPhail, K.L.; Correa, J.; Linington, R.G.; Gonzalez, J.; Ortega-Barria, E.; Capson, T.L.; Gerwick, W.H. Antimalarial linear lipopeptides from a Panamanian strain of the marine cyanobacterium Lyngbya majuscula. J. Nat. Prod. 2007, 70, 984-988. [CrossRef]

59. Hooper, G.J.; Orjala, J.; Schatzman, R.C.; Gerwick, W.H. Carmabins A and B, new lipopeptides from the Caribbean cyanobacterium Lyngbya majuscula. J. Nat. Prod. 1998, 61, 529-533. [CrossRef]

60. Choi, H.; Mevers, E.; Byrum, T.; Valeriote, F.A.; Gerwick, W.H. Lyngbyabellins K-N from two palmyra atoll collections of the marine cyanobacterium Moorea bouillonii. Eur. J. Org. Chem. 2012, 2012, 5141-5150. [CrossRef] 
61. Han, B.; McPhail, K.L.; Gross, H.; Goeger, D.E.; Mooberry, S.L.; Gerwick, W.H.J.T. Isolation and structure of five lyngbyabellin derivatives from a Papua New Guinea collection of the marine cyanobacterium Lyngbya majuscula. Tetrahedron 2005, 61, 11723-11729. [CrossRef]

62. Schmidt, E.W.; Nelson, J.T.; Rasko, D.A.; Sudek, S.; Eisen, J.A.; Haygood, M.G.; Ravel, J. Patellamide A and C biosynthesis by a microcin-like pathway in Prochloron didemni, the cyanobacterial symbiont of Lissoclinum patella. Proc. Natl. Acad. Sci. USA 2005, 102, 7315-7320. [CrossRef] [PubMed]

63. Ziemert, N.; Ishida, K.; Quillardet, P.; Bouchier, C.; Hertweck, C.; de Marsac, N.T.; Dittmann, E. Microcyclamide biosynthesis in two strains of Microcystis aeruginosa: From structure to genes and vice versa. Appl. Environ. Microbiol. 2008, 74, 1791-1797. [CrossRef] [PubMed]

64. Philmus, B.; Christiansen, G.; Yoshida, W.Y.; Hemscheidt, T.K. Post-translational modification in microviridin biosynthesis. Chembiochem 2008, 9, 3066-3073. [CrossRef] [PubMed]

65. Balskus, E.P.; Walsh, C.T. The genetic and molecular basis for sunscreen biosynthesis in cyanobacteria. Science 2010, 329, 1653-1656. [CrossRef]

66. Tan, L.T.; Chang, Y.Y.; Ashootosh, T. Besarhanamides A and B from the marine cyanobacterium Lyngbya majuscula. Phytochemistry 2008, 69, 2067-2069. [CrossRef] [PubMed]

67. Essack, M.; Alzubaidy, H.S.; Bajic, V.B.; Archer, J.A. Chemical compounds toxic to invertebrates isolated from marine cyanobacteria of potential relevance to the agricultural industry. Toxins (Basel) 2014, 6, 3058-3076. [CrossRef] [PubMed]

68. Stewart, I.; Schluter, P.J.; Shaw, G.R. Cyanobacterial lipopolysaccharides and human health-A review. Environ. Health 2006, 5, 7. [CrossRef]

69. Chirasuwan, N.; Chaiklahan, R.; Ruengjitchatchawalya, M.; Bunnag, B.; Tanticharoen, M.J.A.; Resources, N. Anti HSV-1 activity of Spirulina platensis polysaccharide. Kasetsart J. (Nat. Sci.) 2007, 41, 311-318.

70. de Jesus Raposo, M.F.; De Morais, A.M.B.; De Morais, R.M.S.C. Marine polysaccharides from algae with potential biomedical applications. Mar. Drugs 2015, 13, 2967-3028. [CrossRef]

71. Delattre, C.; Pierre, G.; Laroche, C.; Michaud, P. Production, extraction and characterization of microalgal and cyanobacterial exopolysaccharides. Biotechnol. Adv. 2016, 34, 1159-1179. [CrossRef]

72. Moore, R.E. Toxins, anticancer agents, and tumor promoters from marine prokaryotes. Pure Appl. Chem. 1982, 54, 1919-1934. [CrossRef]

73. Banker, R.; Carmeli, S. Tenuecyclamides A-D, cyclic hexapeptides from the cyanobacterium Nostoc spongiaeforme var. tenue. J. Nat. Prod. 1998, 61, 1248-1251. [CrossRef] [PubMed]

74. Blin, K.; Shaw, S.; Steinke, K.; Villebro, R.; Ziemert, N.; Lee, S.Y.; Medema, M.H.; Weber, T. antiSMASH 5.0: Updates to the secondary metabolite genome mining pipeline. Nucleic Acids Res. 2019, 47, W81-W87. [CrossRef] [PubMed]

75. Gershenzon, J.; Dudareva, N. The function of terpene natural products in the natural world. Nat. Chem. Biol. 2007, 3, 408-414. [CrossRef]

76. Pattanaik, B.; Lindberg, P. Terpenoids and their biosynthesis in cyanobacteria. Life 2015, 5, 269-293. [CrossRef]

77. Belin, B.J.; Busset, N.; Giraud, E.; Molinaro, A.; Silipo, A.; Newman, D.K. Hopanoid lipids: From membranes to plant-bacteria interactions. Nat. Rev. Microbiol. 2018, 16, 304. [CrossRef]

78. Takaichi, S.; Mochimaru, M. Carotenoids and carotenogenesis in cyanobacteria: Unique ketocarotenoids and carotenoid glycosides. Cell. Mol. Life Sci. 2007, 64, 2607. [CrossRef]

79. Prasanna, R.; Sood, A.; Jaiswal, P.; Nayak, S.; Gupta, V.; Chaudhary, V.; Joshi, M.; Natarajan, C. Rediscovering cyanobacteria as valuable sources of bioactive compounds. Appl. Biochem. Microbiol. 2010, 46, 119-134. [CrossRef]

80. Na, S.I.; Kim, Y.O.; Yoon, S.H.; Ha, S.M.; Baek, I.; Chun, J. UBCG: Up-to-date bacterial core gene set and pipeline for phylogenomic tree reconstruction. J. Microbiol. 2018, 56, 280-285. [CrossRef]

81. Stamatakis, A. RAxML version 8: A tool for phylogenetic analysis and post-analysis of large phylogenies. Bioinformatics 2014, 30, 1312-1313. [CrossRef]

82. Mejean, A.; Mann, S.; Vassiliadis, G.; Lombard, B.; Loew, D.; Ploux, O. In vitro reconstitution of the first steps of anatoxin-a biosynthesis in Oscillatoria PCC 6506: From free L-proline to acyl carrier protein bound dehydroproline. Biochemistry 2010, 49, 103-113. [CrossRef] [PubMed]

83. Dittmann, E.; Gugger, M.; Sivonen, K.; Fewer, D.P. Natural product biosynthetic diversity and comparative genomics of the cyanobacteria. Trends Microbiol. 2015, 23, 642-652. [CrossRef] [PubMed] 
84. Balskus, E.P.; Walsh, C.T. Investigating the initial steps in the biosynthesis of cyanobacterial sunscreen scytonemin. J. Am. Chem. Soc. 2008, 130, 15260-15261. [CrossRef] [PubMed]

85. Ansari, M.Z.; Yadav, G.; Gokhale, R.S.; Mohanty, D. NRPS-PKS: A knowledge-based resource for analysis of NRPS/PKS megasynthases. Nucleic Acids Res. 2004, 32, W405-W413. [CrossRef] [PubMed]

86. Méjean, A.; Ploux, O. A genomic view of secondary metabolite production in cyanobacteria. In Advances in Botanical Research; Elsevier: Amsterdam, The Netherlands, 2013; Volume 65, pp. 189-234.

87. Arnison, P.G.; Bibb, M.J.; Bierbaum, G.; Bowers, A.A.; Bugni, T.S.; Bulaj, G.; Camarero, J.A.; Campopiano, D.J.; Challis, G.L.; Clardy, J. Ribosomally synthesized and post-translationally modified peptide natural products: Overview and recommendations for a universal nomenclature. Nat. Prod. Rep. 2013, 30, 108-160. [CrossRef]

88. Montalbán-López, M.; Scott, T.A.; Ramesh, S.; Rahman, I.R.; van Heel, A.J.; Viel, J.H.; Bandarian, V.; Dittmann, E.; Genilloud, O.; Goto, Y. New developments in RiPP discovery, enzymology and engineering. Nat. Prod. Rep. 2020. [CrossRef]

89. Han, B.; McPhail, K.L.; Ligresti, A.; Di Marzo, V.; Gerwick, W.H. Semiplenamides A-G, Fatty acid amides from a Papua New Guinea collection of the marina cyanobacterium Lyngbya semiplena. J. Nat. Prod. 2003, 66, 1364-1368. [CrossRef]

90. Chi, Z.; Su, C.; Lu, W. A new exopolysaccharide produced by marine Cyanothece sp. 113. Bioresour. Technol. 2007, 98, 1329-1332. [CrossRef]

91. Markou, G.; Nerantzis, E. Microalgae for high-value compounds and biofuels production: A review with focus on cultivation under stress conditions. Biotechnol. Adv. 2013, 31, 1532-1542. [CrossRef]

92. Delattre, C.; Vijayalakshmi, M. Monolith enzymatic microreactor at the frontier of glycomic toward a new route for the production of bioactive oligosaccharides. J. Mol. Catal. B Enzym. 2009, 60, 97-105. [CrossRef]

93. Kraan, S. Algal polysaccharides, novel applications and outlook. In Carbohydrates-Comprehensive Studies on Glycobiology and Glycotechnology; IntechOpen: London, UK, 2012.

94. Mišurcová, L.; Orsavová, J.; Vávra Ambrožová, J. Algal polysaccharides and health. Polysacch. Bioactivity Biotechnol. 2015, 1, 109-144.

95. Skjånes, K.; Rebours, C.; Lindblad, P. Potential for green microalgae to produce hydrogen, pharmaceuticals and other high value products in a combined process. Crit. Rev. Biotechnol. 2013, 33, 172-215. [CrossRef] [PubMed]

96. Swain, S.S.; Paidesetty, S.K.; Padhy, R.N. Antibacterial, antifungal and antimycobacterial compounds from cyanobacteria. Biomed. Pharmacother. 2017, 90, 760-776. [CrossRef]

97. Liu, X.; Miao, R.; Lindberg, P.; Lindblad, P. Modular engineering for efficient photosynthetic biosynthesis of 1-butanol from $\mathrm{CO}_{2}$ in cyanobacteria. Energy Environ. Sci. 2019, 12, 2765-2777. [CrossRef]

98. Liang, F.; Englund, E.; Lindberg, P.; Lindblad, P. Engineered cyanobacteria with enhanced growth show increased ethanol production and higher biofuel to biomass ratio. Metab. Eng. 2018, 46, 51-59. [CrossRef]

99. Shabestary, K.; Anfelt, J.; Ljungqvist, E.; Jahn, M.; Yao, L.; Hudson, E.P. Targeted repression of essential genes to arrest growth and increase carbon partitioning and biofuel titers in cyanobacteria. ACS Synth. Biol. 2018, 7, 1669-1675. [CrossRef]

100. Xia, P.F.; Ling, H.; Foo, J.L.; Chang, M.W. Synthetic biology toolkits for metabolic engineering of cyanobacteria. Biotechnol. J. 2019, 14, e1800496. [CrossRef]

101. Behler, J.; Vijay, D.; Hess, W.R.; Akhtar, M.K. CRISPR-based technologies for metabolic engineering in cyanobacteria. Trends Biotechnol. 2018, 36, 996-1010. [CrossRef]

102. Fagundes, M.B.; Vendruscolo, R.G.; Maroneze, M.M.; Barin, J.S.; de Menezes, C.R.; Zepka, L.Q.; Jacob-Lopes, E.; Wagner, R. Towards a sustainable route for the production of squalene using cyanobacteria. Waste Biomass Valorization 2019, 10, 1295-1302. [CrossRef]

103. Choi, S.Y.; Lee, H.J.; Choi, J.; Kim, J.; Sim, S.J.; Um, Y.; Kim, Y.; Lee, T.S.; Keasling, J.D.; Woo, H.M. Photosynthetic conversion of $\mathrm{CO}_{2}$ to farnesyl diphosphate-derived phytochemicals (amorpha-4, 11-diene and squalene) by engineered cyanobacteria. Biotechnol. Biofuels 2016, 9, 1-12. [CrossRef]

104. Choi, S.Y.; Wang, J.-Y.; Kwak, H.S.; Lee, S.-M.; Um, Y.; Kim, Y.; Sim, S.J.; Choi, J.-I.; Woo, H.M. Improvement of squalene production from $\mathrm{CO}_{2}$ in Synechococcus elongatus PCC 7942 by metabolic engineering and scalable production in a photobioreactor. ACS Synth. Biol. 2017, 6, 1289-1295. [CrossRef] [PubMed]

105. Choi, S.Y.; Woo, H.M. CRISPRi-dCas12a: A dCas12a-mediated CRISPR interference for repression of multiple genes and metabolic engineering in cyanobacteria. ACS Synth. Biol. 2020, 9, 2351-2361. [CrossRef] [PubMed] 
106. Farruggia, C.; Kim, M.-B.; Bae, M.; Lee, Y.; Pham, T.X.; Yang, Y.; Han, M.J.; Park, Y.-K.; Lee, J.-Y. Astaxanthin exerts anti-inflammatory and antioxidant effects in macrophages in NRF2-dependent and independent manners. J. Nutr. Biochem. 2018, 62, 202-209. [CrossRef] [PubMed]

107. Diao, J.; Song, X.; Zhang, L.; Cui, J.; Chen, L.; Zhang, W. Tailoring cyanobacteria as a new platform for highly efficient synthesis of astaxanthin. Metab. Eng. 2020, 61, 275-287. [CrossRef]

108. Lan, E.I.; Wei, C.T. Metabolic engineering of cyanobacteria for the photosynthetic production of succinate. Metab. Eng. 2016, 38, 483-493. [CrossRef]

109. Song, K.; Tan, X.; Liang, Y.; Lu, X. The potential of Synechococcus elongatus UTEX 2973 for sugar feedstock production. Appl. Microbiol. Biotechnol. 2016, 100, 7865-7875. [CrossRef]

110. Chaves, J.E.; Rueda-Romero, P.; Kirst, H.; Melis, A. Engineering isoprene synthase expression and activity in cyanobacteria. ACS Synth. Biol. 2017, 6, 2281-2292. [CrossRef]

111. Hirokawa, Y.; Dempo, Y.; Fukusaki, E.; Hanai, T. Metabolic engineering for isopropanol production by an engineered cyanobacterium, Synechococcus elongatus PCC 7942, under photosynthetic conditions. J. Biosci. Bioeng. 2017, 123, 39-45. [CrossRef]

112. Formighieri, C.; Melis, A. Heterologous synthesis of geranyllinalool, a diterpenol plant product, in the cyanobacterium Synechocystis. Appl. Microbiol. Biotechnol. 2017, 101, 2791-2800. [CrossRef]

113. Lai, M.J.; Lan, E.I. Photoautotrophic synthesis of butyrate by metabolically engineered cyanobacteria. Biotechnol. Bioeng. 2019, 116, 893-903. [CrossRef]

114. Ehira, S.; Takeuchi, T.; Higo, A. Spatial separation of photosynthesis and ethanol production by cell type-specific metabolic engineering of filamentous cyanobacteria. Appl. Microbiol. Biotechnol. 2018, 102, 1523-1531. [CrossRef] [PubMed]

115. Qiao, C.; Duan, Y.; Zhang, M.; Hagemann, M.; Luo, Q.; Lu, X. Effects of reduced and enhanced glycogen pools on salt-induced sucrose production in a sucrose-secreting strain of Synechococcus elongatus PCC 7942. Appl. Environ. Microbiol. 2018, 84, e02023. [CrossRef] [PubMed]

116. Ku, J.T.; Lan, E.I. A balanced ATP driving force module for enhancing photosynthetic biosynthesis of 3-hydroxybutyrate from $\mathrm{CO}_{2}$. Metab. Eng. 2018, 46, 35-42. [CrossRef]

117. Sarnaik, A.; Abernathy, M.H.; Han, X.; Ouyang, Y.; Xia, K.; Chen, Y.; Cress, B.; Zhang, F.; Lali, A.; Pandit, R. Metabolic engineering of cyanobacteria for photoautotrophic production of heparosan, a pharmaceutical precursor of heparin. Algal Res. 2019, 37, 57-63. [CrossRef]

118. Chin, T.; Okuda, Y.; Ikeuchi, M. Improved sorbitol production and growth in cyanobacteria using promiscuous haloacid dehalogenase-like hydrolase. J. Biotechnol. X 2019, 1, 100002. [CrossRef]

119. Betterle, N.; Melis, A. Photosynthetic generation of heterologous terpenoids in cyanobacteria. Biotechnol. Bioeng. 2019, 116, 2041-2051. [CrossRef]

120. Lee, H.J.; Son, J.; Sim, S.J.; Woo, H.M. Metabolic rewiring of synthetic pyruvate dehydrogenase bypasses for acetone production in cyanobacteria. Plant. Biotechnol. J. 2020, 18, 1860-1868. [CrossRef] [PubMed]

121. Fan, E.S.; Lu, K.W.; Wen, R.C.; Shen, C.R. Photosynthetic reduction of xylose to xylitol using cyanobacteria. Biotechnol. J. 2020, 15, 1900354. [CrossRef] [PubMed]

122. Qiao, Y.; Wang, W.; Lu, X. Engineering cyanobacteria as cell factories for direct trehalose production from $\mathrm{CO}_{2}$. Metab. Eng. 2020, 62, 161-171. [CrossRef] [PubMed]

123. Pattharaprachayakul, N.; Lee, H.J.; Incharoensakdi, A.; Woo, H.M. Evolutionary engineering of cyanobacteria to enhance the production of $\alpha$-farnesene from $\mathrm{CO}_{2}$. J. Agric. Food Chem. 2019, 67, 13658-13664. [CrossRef]

124. Nishiguchi, H.; Hiasa, N.; Uebayashi, K.; Liao, J.; Shimizu, H.; Matsuda, F. Transomics data-driven, ensemble kinetic modeling for system-level understanding and engineering of the cyanobacteria central metabolism. Metab. Eng. 2019, 52, 273-283. [CrossRef] [PubMed]

125. Wang, X.; Liu, W.; Xin, C.; Zheng, Y.; Cheng, Y.; Sun, S.; Li, R.; Zhu, X.-G.; Dai, S.Y.; Rentzepis, P.M. Enhanced limonene production in cyanobacteria reveals photosynthesis limitations. Proc. Natl. Acad. Sci. USA 2016, 113, 14225-14230. [CrossRef] [PubMed]

126. Selão, T.T.; Jebarani, J.; Ismail, N.A.; Norling, B.; Nixon, P.J. Enhanced production of D-lactate in cyanobacteria by re-routing photosynthetic cyclic and pseudo-cyclic electron flow. Front. Plant. Sci. 2019, 10, 1700. [CrossRef] [PubMed]

127. Pade, N.; Erdmann, S.; Enke, H.; Dethloff, F.; Dühring, U.; Georg, J.; Wambutt, J.; Kopka, J.; Hess, W.R.; Zimmermann, R. Insights into isoprene production using the cyanobacterium Synechocystis sp. PCC 6803. Biotechnol. Biofuels 2016, 9, 89. [CrossRef] 
128. Wlodarczyk, A.; Gnanasekaran, T.; Nielsen, A.Z.; Zulu, N.N.; Mellor, S.B.; Luckner, M.; Thøfner, J.F.B.; Olsen, C.E.; Mottawie, M.S.; Burow, M. Metabolic engineering of light-driven cytochrome P450 dependent pathways into Synechocystis sp. PCC 6803. Metab. Eng. 2016, 33, 1-11. [CrossRef] [PubMed]

129. Videau, P.; Wells, K.N.; Singh, A.J.; Gerwick, W.H.; Philmus, B. Assessment of Anabaena sp. strain PCC 7120 as a heterologous expression host for cyanobacterial natural products: Production of lyngbyatoxin A. ACS Synth. Biol. 2016, 5, 978-988. [CrossRef] [PubMed]

130. Yang, G.; Cozad, M.A.; Holland, D.A.; Zhang, Y.; Luesch, H.; Ding, Y. Photosynthetic production of sunscreen shinorine using an engineered cyanobacterium. ACS Synth. Biol. 2018, 7, 664-671. [CrossRef]

131. Knoot, C.J.; Khatri, Y.; Hohlman, R.M.; Sherman, D.H.; Pakrasi, H.B. Engineered production of hapalindole alkaloids in the cyanobacterium Synechococcus sp. UTEX 2973. ACS Synth. Biol. 2019, 8, 1941-1951. [CrossRef]

132. Nozzi, N.E.; Case, A.E.; Carroll, A.L.; Atsumi, S. Systematic approaches to efficiently produce 2, 3-butanediol in a marine cyanobacterium. ACS Synth. Biol. 2017, 6, 2136-2144. [CrossRef]

133. Miao, R.; Liu, X.; Englund, E.; Lindberg, P.; Lindblad, P. Isobutanol production in Synechocystis PCC 6803 using heterologous and endogenous alcohol dehydrogenases. Metab. Eng. Commun. 2017, 5, 45-53. [CrossRef]

134. Lin, P.-C.; Saha, R.; Zhang, F.; Pakrasi, H.B. Metabolic engineering of the pentose phosphate pathway for enhanced limonene production in the cyanobacterium Synechocysti s sp. PCC 6803. Sci. Rep. 2017, 7, 1-10. [CrossRef] [PubMed]

135. Li, H.; Shen, C.R.; Huang, C.-H.; Sung, L.-Y.; Wu, M.-Y.; Hu, Y.-C. CRISPR-Cas9 for the genome engineering of cyanobacteria and succinate production. Metab. Eng. 2016, 38, 293-302. [CrossRef] [PubMed]

136. Kaczmarzyk, D.; Cengic, I.; Yao, L.; Hudson, E.P. Diversion of the long-chain acyl-ACP pool in Synechocystis to fatty alcohols through CRISPRi repression of the essential phosphate acyltransferase PlsX. Metab. Eng. 2018, 45, 59-66. [CrossRef] [PubMed]

137. Luan, G.; Zhang, S.; Lu, X. Engineering cyanobacteria chassis cells toward more efficient photosynthesis. Curr. Opin. Biotechnol. 2020, 62, 1-6. [CrossRef] [PubMed]

138. Yang, D.; Park, S.Y.; Park, Y.S.; Eun, H.; Lee, S.Y. Metabolic engineering of Escherichia coli for natural product biosynthesis. Trends Biotechnol. 2020, 38, 745-765. [CrossRef] [PubMed]

139. Santos-Merino, M.; Singh, A.K.; Ducat, D.C. New applications of synthetic biology tools for cyanobacterial metabolic engineering. Front. Bioeng. Biotechnol. 2019, 7, 33. [CrossRef]

140. Singh, S. Cyanoomics: An advancement in the fields cyanobacterial omics biology with special reference to proteomics and transcriptomics. In Advances in Cyanobacterial Biology; Elsevier: Amsterdam, The Netherlands, 2020; pp. 163-171.

141. Ferreira, E.A.; Pacheco, C.C.; Pinto, F.; Pereira, J.; Lamosa, P.; Oliveira, P.; Kirov, B.; Jaramillo, A.; Tamagnini, P. Expanding the toolbox for Synechocystis sp. PCC 6803: Validation of replicative vectors and characterization of a novel set of promoters. Synth. Biol. 2018, 3, ysy014. [CrossRef]

142. Wang, B.; Eckert, C.; Maness, P.-C.; Yu, J. A genetic toolbox for modulating the expression of heterologous genes in the cyanobacterium Synechocystis sp. PCC 6803. ACS Synth. Biol. 2018, 7, 276-286. [CrossRef]

143. Sengupta, A.; Madhu, S.; Wangikar, P.P. A Library of tunable, portable, and inducer-free promoters derived from cyanobacteria. ACS Synth. Biol. 2020, 9, 1790-1801. [CrossRef]

144. Thiel, K.; Mulaku, E.; Dandapani, H.; Nagy, C.; Aro, E.-M.; Kallio, P. Translation efficiency of heterologous proteins is significantly affected by the genetic context of RBS sequences in engineered cyanobacterium Synechocystis sp. PCC 6803. Microb. Cell Fact. 2018, 17, 34. [CrossRef]

145. Heidorn, T.; Camsund, D.; Huang, H.-H.; Lindberg, P.; Oliveira, P.; Stensjö, K.; Lindblad, P. Synthetic biology in cyanobacteria: Engineering and analyzing novel functions. In Methods in Enzymology; Elsevier: Amsterdam, The Netherlands, 2011; Volume 497, pp. 539-579.

146. Liu, D.; Pakrasi, H.B. Exploring native genetic elements as plug-in tools for synthetic biology in the cyanobacterium Synechocystis sp. PCC 6803. Microb. Cell Fact. 2018, 17, 1-8. [CrossRef] [PubMed]

147. Nakahira, Y.; Ogawa, A.; Asano, H.; Oyama, T.; Tozawa, Y. Theophylline-dependent riboswitch as a novel genetic tool for strict regulation of protein expression in cyanobacterium Synechococcus elongatus PCC 7942. Plant. Cell Physiol. 2013, 54, 1724-1735. [CrossRef] [PubMed]

148. Chi, X.; Zhang, S.; Sun, H.; Duan, Y.; Qiao, C.; Luan, G.; Lu, X. Adopting a theophylline-responsive riboswitch for flexible regulation and understanding of glycogen metabolism in Synechococcus elongatus PCC7942. Front. Microbiol. 2019, 10, 551. [CrossRef] [PubMed] 
149. Ma, A.T.; Schmidt, C.M.; Golden, J.W. Regulation of gene expression in diverse cyanobacterial species by using theophylline-responsive riboswitches. Appl. Environ. Microbiol. 2014, 80, 6704-6713. [CrossRef]

150. Higo, A.; Ehira, S. Anaerobic butanol production driven by oxygen-evolving photosynthesis using the heterocyst-forming multicellular cyanobacterium Anabaena sp. PCC 7120. Appl. Microbiol. Biotechnol. 2019, 103, 2441-2447. [CrossRef]

151. Kaneko, T.; Tabata, S. Complete genome structure of the unicellular cyanobacterium Synechocystis sp. PCC6803. Plant Cell Physiol. 1997, 38, 1171-1176. [CrossRef]

152. Yang, H.W.; Song, J.Y.; Cho, S.M.; Kwon, H.C.; Pan, C.-H.; Park, Y.-I. Genomic survey of salt acclimation-related genes in the halophilic cyanobacterium Euhalothece sp. Z-M001. Sci. Rep. 2020, 10, 676. [CrossRef]

153. Tan, X.; Hou, S.; Song, K.; Georg, J.; Klähn, S.; Lu, X.; Hess, W.R. The primary transcriptome of the fast-growing cyanobacterium Synechococcus elongatus UTEX 2973. Biotechnol. Biofuels 2018, 11, 218. [CrossRef]

154. Koch, R.; Kupczok, A.; Stucken, K.; Ilhan, J.; Hammerschmidt, K.; Dagan, T. Plasticity first: Molecular signatures of a complex morphological trait in filamentous cyanobacteria. BMC Evol. Biol. 2017, 17, 1-11. [CrossRef]

155. Karlsen, J.; Asplund-Samuelsson, J.; Thomas, Q.; Jahn, M.; Hudson, E.P. Ribosome profiling of Synechocystis reveals altered ribosome allocation at carbon starvation. mSystems 2018, 3, e00126. [CrossRef]

156. Jahn, M.; Vialas, V.; Karlsen, J.; Maddalo, G.; Edfors, F.; Forsström, B.; Uhlén, M.; Käll, L.; Hudson, E.P. Growth of cyanobacteria is constrained by the abundance of light and carbon assimilation proteins. Cell Rep. 2018, 25, 478-486.e478. [CrossRef] [PubMed]

157. Yang, C.; Hua, Q.; Shimizu, K. Metabolic flux analysis in Synechocystis using isotope distribution from 13C-labeled glucose. Metab. Eng. 2002, 4, 202-216. [CrossRef] [PubMed]

158. Shastri, A.A.; Morgan, J.A. Flux balance analysis of photoautotrophic metabolism. Biotechnol. Prog. 2005, 21, 1617-1626. [CrossRef] [PubMed]

159. Yoshikawa, K.; Kojima, Y.; Nakajima, T.; Furusawa, C.; Hirasawa, T.; Shimizu, H. Reconstruction and verification of a genome-scale metabolic model for Synechocystis sp. PCC6803. Appl. Microbiol. Biotechnol. 2011, 92, 347. [CrossRef]

160. Toyoshima, M.; Toya, Y.; Shimizu, H. Flux balance analysis of cyanobacteria reveals selective use of photosynthetic electron transport components under different spectral light conditions. Photosynth. Res. 2020, 143, 31-43. [CrossRef]

161. Qian, X.; Kim, M.K.; Kumaraswamy, G.K.; Agarwal, A.; Lun, D.S.; Dismukes, G.C. Flux balance analysis of photoautotrophic metabolism: Uncovering new biological details of subsystems involved in cyanobacterial photosynthesis. Biochim. Biophys. Acta Bioenerg. 2017, 1858, 276-287. [CrossRef]

162. Guerreiro, A.C.; Penning, R.; Raaijmakers, L.M.; Axman, I.M.; Heck, A.J.; Altelaar, A.M. Monitoring light/dark association dynamics of multi-protein complexes in cyanobacteria using size exclusion chromatography-based proteomics. J. Proteom. 2016, 142, 33-44. [CrossRef]

163. Liberton, M.; Saha, R.; Jacobs, J.M.; Nguyen, A.Y.; Gritsenko, M.A.; Smith, R.D.; Koppenaal, D.W.; Pakrasi, H.B. Global proteomic analysis reveals an exclusive role of thylakoid membranes in bioenergetics of a model cyanobacterium. Mol. Cell Proteom. 2016, 15, 2021-2032. [CrossRef]

164. Choi, S.Y.; Park, B.; Choi, I.-G.; Sim, S.J.; Lee, S.-M.; Um, Y.; Woo, H.M. Transcriptome landscape of Synechococcus elongatus PCC 7942 for nitrogen starvation responses using RNA-seq. Sci. Rep. 2016, 6, 30584. [CrossRef]

165. Kizawa, A.; Kawahara, A.; Takimura, Y.; Nishiyama, Y.; Hihara, Y. RNA-seq profiling reveals novel target genes of LexA in the cyanobacterium Synechocystis sp. PCC 6803. Front. Microbiol. 2016, 7, 193. [CrossRef]

166. Lin, X.; Ding, H.; Zeng, Q. Transcriptomic response during phage infection of a marine cyanobacterium under phosphorus-limited conditions. Environ. Microbiol. 2016, 18, 450-460. [CrossRef] [PubMed]

167. Gonzalez, A.; Bes, M.T.; Peleato, M.L.; Fillat, M.F. Expanding the role of FurA as essential global regulator in cyanobacteria. PLoS ONE 2016, 11, e0151384. [CrossRef] [PubMed]

168. Hood, R.D.; Higgins, S.A.; Flamholz, A.; Nichols, R.J.; Savage, D.F. The stringent response regulates adaptation to darkness in the cyanobacterium Synechococcus elongatus. Proc. Natl. Acad. Sci. USA 2016, 113, E4867-E4876. [CrossRef] [PubMed]

169. Harke, M.J.; Jankowiak, J.G.; Morrell, B.K.; Gobler, C.J. Transcriptomic responses in the bloom-forming cyanobacterium Microcystis induced during exposure to zooplankton. Appl. Environ. Microbiol. 2017, 83, e02832. [CrossRef] [PubMed] 
170. Hendry, J.I.; Prasannan, C.; Ma, F.; Möllers, K.B.; Jaiswal, D.; Digmurti, M.; Allen, D.K.; Frigaard, N.U.; Dasgupta, S.; Wangikar, P.P. Rerouting of carbon flux in a glycogen mutant of cyanobacteria assessed via isotopically non-stationary 13C metabolic flux analysis. Biotechnol. Bioeng. 2017, 114, 2298-2308. [CrossRef] [PubMed]

171. Hirokawa, Y.; Matsuo, S.; Hamada, H.; Matsuda, F.; Hanai, T. Metabolic engineering of Synechococcus elongatus PCC 7942 for improvement of 1, 3-propanediol and glycerol production based on in silico simulation of metabolic flux distribution. Microb. Cell Fact. 2017, 16, 1-12. [CrossRef] [PubMed]

172. Jazmin, L.J.; Xu, Y.; Cheah, Y.E.; Adebiyi, A.O.; Johnson, C.H.; Young, J.D. Isotopically nonstationary 13C flux analysis of cyanobacterial isobutyraldehyde production. Metab. Eng. 2017, 42, 9-18. [CrossRef]

173. Nakajima, T.; Yoshikawa, K.; Toya, Y.; Matsuda, F.; Shimizu, H. Metabolic flux analysis of the Synechocystis sp. PCC $6803 \triangle$ nrtABCD mutant reveals a mechanism for metabolic adaptation to nitrogen-limited conditions. Plant. Cell Physiol. 2017, 58, 537-545. [CrossRef]

174. Sun, T.; Chen, L.; Zhang, W. Quantitative proteomics reveals potential crosstalk between a small RNA CoaR and a two-component regulator Slr1037 in Synechocystis sp. PCC6803. J. Proteome Res. 2017, 16, 2954-2963. [CrossRef]

175. Liberton, M.; Chrisler, W.B.; Nicora, C.D.; Moore, R.J.; Smith, R.D.; Koppenaal, D.W.; Pakrasi, H.B.; Jacobs, J.M. Phycobilisome truncation causes widespread proteome changes in Synechocystis sp. PCC 6803. PLoS ONE 2017, 12, e0173251. [CrossRef]

176. Ge, H.; Fang, L.; Huang, X.; Wang, J.; Chen, W.; Liu, Y.; Zhang, Y.; Wang, X.; Xu, W.; He, Q. Translating divergent environmental stresses into a common proteome response through the histidine kinase 33 (Hik33) in a model cyanobacterium. Mol. Cell Proteom. 2017, 16, 1258-1274. [CrossRef] [PubMed]

177. Mackey, K.R.; Post, A.F.; McIlvin, M.R.; Saito, M.A. Physiological and proteomic characterization of light adaptations in marine Synechococcus. Environ. Microbiol. 2017, 19, 2348-2365. [CrossRef] [PubMed]

178. Muñoz-Marín, M.d.C.; Gómez-Baena, G.; Díez, J.; Beynon, R.J.; González-Ballester, D.; Zubkov, M.V.; García-Fernández, J.M. Glucose uptake in Prochlorococcus: Diversity of kinetics and effects on the metabolism. Front. Microbiol. 2017, 8, 327. [CrossRef] [PubMed]

179. Domínguez-Martín, M.A.; Gómez-Baena, G.; Díez, J.; López-Grueso, M.J.; Beynon, R.J.; García-Fernández,J.M. Quantitative proteomics shows extensive remodeling induced by nitrogen limitation in Prochlorococcus marinus SS120. MSystems 2017, 2, 3. [CrossRef]

180. Fang, L.; Ge, H.; Huang, X.; Liu, Y.; Lu, M.; Wang, J.; Chen, W.; Xu, W.; Wang, Y. Trophic mode-dependent proteomic analysis reveals functional significance of light-independent chlorophyll synthesis in Synechocystis sp. PCC 6803. Mol. Plant. 2017, 10, 73-85. [CrossRef]

181. Wang, J.; Chen, L.; Chen, Z.; Zhang, W. RNA-seq based transcriptomic analysis of single bacterial cells. Integr. Biol. 2015, 7, 1466-1476. [CrossRef]

182. Giner-Lamia, J.; Robles-Rengel, R.; Hernández-Prieto, M.A.; Muro-Pastor, M.I.; Florencio, F.J.; Futschik, M.E. Identification of the direct regulon of NtcA during early acclimation to nitrogen starvation in the cyanobacterium Synechocystis sp. PCC 6803. Nucleic Acids Res. 2017, 45, 11800-11820. [CrossRef]

183. Newby, R., Jr.; Lee, L.H.; Perez, J.L.; Tao, X.; Chu, T. Characterization of zinc stress response in Cyanobacterium Synechococcus sp. IU 625. Aquat. Toxicol. 2017, 186, 159-170. [CrossRef]

184. Joshi, C.J.; Peebles, C.A.; Prasad, A. Modeling and analysis of flux distribution and bioproduct formation in Synechocystis sp. PCC 6803 using a new genome-scale metabolic reconstruction. Algal Res. 2017, 27, 295-310. [CrossRef]

185. Malatinszky, D.; Steuer, R.; Jones, P.R. A comprehensively curated genome-scale two-cell model for the heterocystous cyanobacterium Anabaena sp. PCC 7120. Plant. Physiol. 2017, 173, 509-523. [CrossRef]

186. Mueller, T.J.; Ungerer, J.L.; Pakrasi, H.B.; Maranas, C.D. Identifying the metabolic differences of a fast-growth phenotype in Synechococcus UTEX 2973. Sci. Rep. 2017, 7, 41569. [CrossRef] [PubMed]

187. Morimoto, D.; Kimura, S.; Sako, Y.; Yoshida, T. Transcriptome analysis of a bloom-forming cyanobacterium Microcystis aeruginosa during Ma-LMM01 phage infection. Front. Microbiol. 2018, 9, 2. [CrossRef] [PubMed]

188. Abernathy, M.H.; Czajka, J.J.; Allen, D.K.; Hill, N.C.; Cameron, J.C.; Tang, Y.J. Cyanobacterial carboxysome mutant analysis reveals the influence of enzyme compartmentalization on cellular metabolism and metabolic network rigidity. Metab. Eng. 2019, 54, 222-231. [CrossRef]

189. Choi, J.-S.; Park, Y.H.; Oh, J.H.; Kim, S.; Kwon, J.; Choi, Y.-E. Efficient profiling of detergent-assisted membrane proteome in cyanobacteria. J. Appl. Phycol. 2019, 32, 1-8. [CrossRef] 
190. Fang, X.; Liu, Y.; Zhao, Y.; Chen, Y.; Liu, R.; Qin, Q.L.; Li, G.; Zhang, Y.Z.; Chan, W.; Hess, W.R.; et al. Transcriptomic responses of the marine cyanobacterium Prochlorococcus to viral lysis products. Environ. Microbiol. 2019, 21, 2015-2028. [CrossRef] [PubMed]

191. Gonzalez, A.; Riley, K.W.; Harwood, T.V.; Zuniga, E.G.; Risser, D.D. A tripartite, hierarchical sigma factor cascade promotes hormogonium development in the filamentous cyanobacterium Nostoc punctiforme. mSphere 2019, 4, e00231-19. [CrossRef] [PubMed]

192. Hirose, Y.; Chihong, S.; Watanabe, M.; Yonekawa, C.; Murata, K.; Ikeuchi, M.; Eki, T. Diverse chromatic acclimation processes regulating phycoerythrocyanin and rod-shaped phycobilisome in cyanobacteria. Mol. Plant 2019, 12, 715-725. [CrossRef] [PubMed]

193. Jaiswal, D.; Sengupta, A.; Sengupta, S.; Madhu, S.; Pakrasi, H.B.; Wangikar, P.P. A novel cyanobacterium Synechococcus elongatus PCC 11802 has distinct genomic and metabolomic characteristics compared to its neighbor PCC 11801. Sci. Rep. 2020, 10, 191. [CrossRef]

194. May, D.S.; Crnkovic, C.M.; Krunic, A.; Wilson, T.A.; Fuchs, J.R.; Orjala, J.E. (15)N Stable isotope labeling and comparative metabolomics facilitates genome mining in cultured cyanobacteria. ACS Chem. Biol. 2020, 15, 758-765. [CrossRef]

195. Solanki, H.; Pierdet, M.; Thomas, O.P.; Zubia, M. Insights into the metabolome of the cyanobacterium Leibleinia gracilis from the lagoon of Tahiti and first inspection of its variability. Metabolites 2020, 10, 215. [CrossRef]

196. Shi, M.; Chen, L.; Zhang, W. Regulatory diversity and functional analysis of two-component systems in cyanobacterium Synechocystis sp. PCC 6803 by GC-MS based metabolomics. Front. Microbiol. 2020, 11, 403. [CrossRef] [PubMed]

197. Cui, J.; Sun, T.; Li, S.; Xie, Y.; Song, X.; Wang, F.; Chen, L.; Zhang, W. Improved salt tolerance and metabolomics analysis of Synechococcus elongatus UTEX 2973 by overexpressing Mrp Antiporters. Front. Bioeng. Biotechnol. 2020, 8, 500. [CrossRef] [PubMed]

198. Sengupta, A.; Pritam, P.; Jaiswal, D.; Bandyopadhyay, A.; Pakrasi, H.B.; Wangikar, P.P. Photosynthetic co-production of succinate and ethylene in a fast-growing cyanobacterium, Synechococcus elongatus PCC 11801. Metabolites 2020, 10, 250. [CrossRef] [PubMed]

199. Georges des Aulnois, M.; Réveillon, D.; Robert, E.; Caruana, A.; Briand, E.; Guljamow, A.; Dittmann, E.; Amzil, Z.; Bormans, M.J.T. Salt shock responses of Microcystis revealed through physiological, transcript, and metabolomic analyses. Toxins 2020, 12, 192. [CrossRef] [PubMed]

200. de Alvarenga, L.V.; Hess, W.R.; Hagemann, M. AcnSP-A novel small protein regulator of aconitase activity in the cyanobacterium Synechocystis sp. PCC 6803. Front. Microbiol. 2020, 11, 1445. [CrossRef]

201. Popin, R.V.; Delbaje, E.; de Abreu, V.A.C.; Rigonato, J.; Dorr, F.A.; Pinto, E.; Sivonen, K.; Fiore, M.F. Genomic and metabolomic analyses of natural products in Nodularia spumigena isolated from a shrimp culture pond. Toxins (Basel) 2020, 12, 141. [CrossRef]

202. Koksharova, O.A.; Butenko, I.O.; Pobeguts, O.V.; Safronova, N.A.; Govorun, V.M. The first proteomics study of Nostoc sp. PCC 7120 exposed to cyanotoxin BMAA under nitrogen starvation. Toxins (Basel) 2020, 12, 310. [CrossRef]

203. Teoh, F.; Shah, B.; Ostrowski, M.; Paulsen, I. Comparative membrane proteomics reveal contrasting adaptation strategies for coastal and oceanic marine Synechococcus cyanobacteria. Environ. Microbiol. 2020, 22, 1816-1828. [CrossRef]

204. Romeu, M.J.L.; Dominguez-Perez, D.; Almeida, D.; Morais, J.; Campos, A.; Vasconcelos, V.; Mergulhao, F.J.M. Characterization of planktonic and biofilm cells from two filamentous cyanobacteria using a shotgun proteomic approach. Biofouling 2020, 36, 631-645. [CrossRef]

205. He, P.; Cai, X.; Chen, K.; Fu, X. Identification of small RNAs involved in nitrogen fixation in Anabaena sp. PCC 7120 based on RNA-seq under steady state conditions. Ann. Microbiol. 2020, 70, 4. [CrossRef]

206. Mironov, K.S.; Kupriyanova, E.V.; Shumskaya, M.; Los, D.A. Alcohol stress on cyanobacterial membranes: New insights revealed by transcriptomics. Gene 2020, 764, 145055. [CrossRef] [PubMed]

207. Arias, D.B.; Gomez Pinto, K.A.; Cooper, K.K.; Summers, M.L. Transcriptomic analysis of cyanobacterial alkane overproduction reveals stress-related genes and inhibitors of lipid droplet formation. Microb. Genom. 2020, 6, e000432. [CrossRef] [PubMed] 
208. Gordon, G.C.; Cameron, J.C.; Gupta, S.T.P.; Engstrom, M.D.; Reed, J.L.; Pfleger, B.F. Genome-wide analysis of RNA decay in the cyanobacterium Synechococcus sp. strain PCC 7002. mSystems 2020, 5, e00224-20. [CrossRef] [PubMed]

209. Ahmad, A.; Pathania, R.; Srivastava, S. Biochemical Characteristics and a Genome-scale metabolic model of an Indian euryhaline cyanobacterium with high polyglucan content. Metabolites 2020, 10, 177. [CrossRef] [PubMed]

210. Malek Shahkouhi, A.; Motamedian, E. Reconstruction of a regulated two-cell metabolic model to study biohydrogen production in a diazotrophic cyanobacterium Anabaena variabilis ATCC 29413. PLoS ONE 2020, 15, e227977. [CrossRef] [PubMed]

211. Rubin, B.E.; Wetmore, K.M.; Price, M.N.; Diamond, S.; Shultzaberger, R.K.; Lowe, L.C.; Curtin, G.; Arkin, A.P.; Deutschbauer, A.; Golden, S.S. The essential gene set of a photosynthetic organism. Proc. Natl. Acad. Sci. USA 2015, 112, E6634-E6643. [CrossRef]

212. Englund, E.; Liang, F.; Lindberg, P. Evaluation of promoters and ribosome binding sites for biotechnological applications in the unicellular cyanobacterium Synechocystis sp. PCC 6803. Sci. Rep. 2016, 6, 36640. [CrossRef]

Publisher's Note: MDPI stays neutral with regard to jurisdictional claims in published maps and institutional affiliations.

(C) 2020 by the authors. Licensee MDPI, Basel, Switzerland. This article is an open access article distributed under the terms and conditions of the Creative Commons Attribution (CC BY) license (http://creativecommons.org/licenses/by/4.0/). 